$1-1-2003$

\title{
The use of Islamic sources in Saadiah Gaon's Tafsir of the Torah
}

David M. Freidenreich

Colby College, dfreiden@colby.edu

Follow this and additional works at: https://digitalcommons.colby.edu/faculty_scholarship

Part of the Religion Commons

\section{Recommended Citation}

Freidenreich, David M., "The use of Islamic sources in Saadiah Gaon's Tafsir of the Torah" (2003). Faculty Scholarship. 33.

https://digitalcommons.colby.edu/faculty_scholarship/33

This Article is brought to you for free and open access by Digital Commons @ Colby. It has been accepted for inclusion in Faculty Scholarship by an authorized administrator of Digital Commons @ Colby. 


\title{
THE USE OF ISLAMIC SOURCES IN SAADIAH GAON'S TAFSIR OF THE TORAH
}

\author{
David M. Freidenreich, Columbia University
}

\begin{abstract}
Saadiah Gaon's influential translation of the Torah into Arabic has long been known to contain countless "mistranslations," passages in which Saadiah consciously modifies the biblical text to conform to Arabic literary style or to his own beliefs and understanding of the Bible. Several of the modifications found in Saadiah's Tafsir derive from Islamic sources, including Islamic terminology and phraseology, Islamic law and tradition, and the Qur'an itself. This paper examines those passages in the Tafsir of the Torah which reflect Islamic influence in an attempt to understand how, in a work written for a Jewish audience, Saadiah utilizes material gleaned from the dominant religion of his day and why on several occasions the gaon prefers Islamic interpretations over the existing rabbinic and biblical alternatives.
\end{abstract}

Saadiah Gaon's translation of the Torah into Arabic is considered by Joshua Blau, perhaps the foremost living scholar of JudeoArabic, to be "the most influential mediaeval Judeo-Arabic work." The translation, known in Arabic as the Tafsìr, appears to have become the universally accepted Arabic rendition of the Pentateuch among rabbinic Jews within decades of its completion in the early 10th century, and it continues to be used to this day. Saadiah's Tafsir occupies a role similar to Onkelos' better-known Aramaic Targum of the Torah as an authoritative translation popularly studied in religious circles alongside the Hebrew original. In terms of its impact on Jewish culture, Saadiah's biographer Henry Malter ranks the Tafsir alongside such influential works as the Septuagint and Moses Mendelssohn's German translation of the Bible; Malter credits the work with inaugurating the Golden Age of Jewish literary activity in the Arabic-speaking world. ${ }^{2}$

\footnotetext{
'J. Blau, "Some Instances Reflecting the Influence of Saadya Gaon's Bible Translation on Later Judeo-Arabic Writings," in Occident and Orient: A Tribute to the Memory of Alexander Scheiber, ed. R. Dan (Leiden, 1988), p. 21.

${ }^{2}$ H. Malter, Saadiah Gaon: His Life and Works (Philadelphia, 1921), p. 142.
} 
One can consider all translations to be interpretations to some extent, and the Arabic word tafsir itself means "explanation" or "interpretation." As Meira Polliack points out, "Saadiah's awareness of the interpretive nature of his translation of the Pentateuch may explain its designation as tafsir ; a term which better conveys this sense than the term tarjamah" used by later Karaite translators of the Torah. ${ }^{3}$ Indeed, Saadiah's work, especially in light of its Karaite counterparts, is particularly noteworthy for its extensive deviations from the Hebrew original. Scholars have pointed out countless examples of these "mistranslations" and have identified several factors that account for Saadiah's changes. One important factor seems to have been generally overlooked, however, even though examples of its application have themselves been duly noted. On several occasions, Saadiah deviates from the biblical text or its standard rabbinic understanding in favor of an interpretation drawn from the Qur'an or other Islamic sources. An analysis of how Saadiah uses Islamic terms and sources in his Tafsir of the Torah casts new light on the gaon's attitude toward the dominant religion of his time and toward its texts and traditions.

\section{SAADIAH AND HIS TAFSIR}

The outline of Saadiah's biography has been pieced together by modern scholars, but the details remain uncertain. Saadiah was born in 882 in the Fayyüm district of Upper Egypt, spent some time in the Land of Israel, and by the early 920 s was an important figure in Rabbanite circles and the most forceful advocate of the Babylonian position in a rabbinic calendrical dispute. In 928 he was appointed to the position of Gaon of Sura, head of one of the two major rabbinic schools located in Baghdad. Other than a short period in exile due to a controversy with the political head of the Babylonian Jewish community, he remained in that post until his death in $942 .{ }^{4}$ Saa-

${ }^{3}$ M. Polliack, The Karaite Tradition of Arabic Bible Translation: A Linguistic and Exegetical Study of Karaite Translations of the Pentateuch from the Tenth and Eleventh Centuries C.E. (Leiden, 1997), p. 86.

${ }^{4}$ Malter's Saadiah Gaon, written in the 1920 s, remains the only book-length treatment of Saadiah's life in English, although several details of Malter's account (such as Saadiah's year of birth) have been proven incorrect on the basis of evidence from the Cairo Genizah. See A. Marx, "Rab Saadia Gaon," in Rab Saadia Gaon: Studies in His Honor, ed. L. Finkelstein (New York, 1944), pp. 53-97, for a briefer biography diah's writings include works on grammar and astronomy, biblical and halakhic commentary, and, the field with which he is perhaps most associated, philosophy. For the most part, however, it is unclear when Saadiah wrote each of his works, and the date of the Tafsir's composition has been the subject of much scholarly conjecture Malter states that the Tafsir was most likely begun while Saadiah was still in Egypt and was revised subsequently; Polliack suggests that Saadiah may have begun his work while in Tiberias but that most of it was composed in Baghdad, while Edward Robertson dates the composition in its entirety to Saadiah's tenure as gaon.

Although there were earlier translations of the Torah into Arabic, Saadiah's Tafsir was the first to gain general acceptance throughout the Arabic-speaking Jewish world; the work's rapid and widespread dissemination can presumably be credited to its quality and to the renown of its author. ${ }^{6}$ Saadiah was the first Arabic translator to stray from a stilted, word-for-word rendering of the biblical text. Quite the contrary, Saadiah took great liberty in preparing his translation. Many of his changes result from the imposition of his own philosophical and theological beliefs onto the Torah, so as to bring its plain meaning into conformity with both reason and rabbinic tradition. Saadiah justifies this approach to translation in the introduction to his Commentary on Genesis, in which he asserts that "it is

that takes into account the significant information about Saadiah's life discovered in the Genizah.

${ }_{5}^{5}$ Malter, Saadiah Gaon, p. 141; Polliack, The Karaite Tradition, p. 77; E. Robertson, "The Relationship of the Arabic Translation of the Samaritan Pentateuch to That of Saadya," in Saadya Studies: In Commemoration of the One Thousandth Anniversary of the Death of R. Saadya Gaon, ed. E. 1. J. Rosenthal (Manchester, 1943), p. 167.

${ }^{6}$ J. Blau, "'Iyyunim bi-Ketav Yad Mizrahi mi-Tchilat ha-Me'ah ha-11 shel Targum Rasag la-Torah," Leshonenu 51 (1998) 111. On Arabic translations of the Torah that preceded Saadiah's Tafsir, see J. Blau, "On a Fragment of the Oldest Judaeo-Arabic Bible Translation Extant," in Genizah Research after Ninety Years: The Case of JudaeoArabic, eds. J. Blau and S. Reif (Cambridge, 1992), pp. 31-39; Y. Tobi, "Seridei Targum “Aravi la-Torah Qodem le-Tafsir Rav Saadiah Gaon," Mesorot 7 (1993) 87-127; Y. Tobi, "Targum 'Aravi-Yehudi ‘Ammami Nosaf la-Torah," in Mehqarim be-Lashon ha-'Ivrit uve-Leshonot ha-Yehudim Mugashim le-Shelomo Morag, cd. M. Bar-Asher (Jerusalcm, 1996), pp. 481-501; M. Polliack, "Arabic Bible Translations in the Cairo Genizah Collection," Jewish Studies in a New Europe (Copenhagen, 1996) pp. 610614; Y. Tobi, "'Al Qadmuto shel Tirgumei ha-Miqra be-'Aravit Yehudit ve-Qeta' miTirgum 'Aravi-Yehudi Qadum la-Migra," in Bein 'Ever le-'Arav, ed. Y. Tobi (Tel Aviv, 2001), pp. 17-60. 
incumbent upon anyone who interprets [the Bible] that he consider [passages] that are in accordance with the rational principles which precede them and the traditions which follow them as reflecting clear language (muhkamāt) and that he consider [passages] that contradict one of these to be ambiguous (mutashäbihät)." ${ }^{7}$ Passages that are "ambiguous" must be clarified in light of reason and tradition. So, for example, Saadiah consistently eliminates anthropomorphic references to God. As he explains in his commentary on Ps 2:4, "verbs of action which refer to God, such as 'He descended,' 'He went up,' and are rationally inadmissible have to be transferred to agents and to be translated 'He made one descend,' 'He caused someone to go up." ${ }^{8}$ In the Tafsir of the Torah, Saadiah applies this principle by translating references to God's physical presence as $n \bar{u} r$ alläh, "the light of God,", as well as making numerous other changes such as rendering "God said" in the creation narrative (Genesis 1) as "God willed," and "The Lord came down" (Exod 19:20) as "The Lord revealed Himself." 10 An example of rabbinic influence on the Tafsìr can be seen in Saadiah's translation of "You shall not boil a kid in its mother's milk" (Exod 23:19, 34:26; Deut 14:21) as "You shal1 not eat meat with milk."11

${ }^{7}$ For the Judeo-Arabic of this passage, see M. Zucker, ed., Perushei Rav Se adiah Ga'on li-Breshil (New York, 1984), p. 17; Zucker offers a Hebrew translation on p. 191. On the parallel usage of the terns muhkamāt and mutashäbihāt in Islarnic literature, see below, n. 21 .

${ }^{8}$ A. S. Halkin, "Saadia's Excgesis and Polcmics," in Rab Saadia Gaon, ed. L. Finkelstein, p. 126

${ }^{9}$ Saadiah consistently uses this phrase when translating verses referring to God's physical presence in which Onkelos uses the word yeqara to modify God's name; on all occasions in which Saadiah deviates from this pattern, he either translates the biblical text without anti-anthropomorphic modification or instead modifies the structure of the verse. The phrase nūr alläh occasionally appears in the gaon's translations of other verses as well, including Num 11:2 (where Onkelos uses the word meimra). On the possibility that Saadiah borrowed this term from Arabic-speaking Christian communities, see below, n. 73 .

${ }^{10}$ All English translations from the Bible, unless otherwise noted, are taken from the Jewish Publication Society's 1985 translation of the Tanakh. Throughout this work, all emphases have been added.

${ }^{11}$ This example is among those which Saadiah himself cites in the introduction to his Commentary; see Zucker, ed.. Perushei Rav Seradiah, pp. 18, 192. Saadiah's examples of non-rational verses that require interpretation are Gen 3:20 (Eve is not "the mother of all the living" but merely "the mother of all the living that are rational and mortal") and Deut 4:24 (God is not "a consuming fire," but rather God's punishment
The Tafsir, as Polliack has amply demonstrated, also reflects the influence of Arabic language and culture. Polliack characterizes Saadiah's translation, in contrast to the later Karaite translations by Yefet b. 'Eli and Yeshu'ah b. Yehudah, as being "communicative" in its purpose. "This type of translation required him to adopt intrinsic forms of the Arabic language and to assimilate recognizable elements of its style." 12 She emphasizes that Saadiah, unlike his Karaite counterparts, is more willing to translate biblical words using their semantic equivalents rather than using cognate words. ${ }^{13} \mathrm{Saa}-$ diah also rephrases biblical sentences to conform to culturally derived standards of proper literary style, without regard to the evident style of the Torah itself. This can be seen clearly in his translation of Genesis 1 , in which the biblical formula which concludes each paragraph of the creation narrative, "And there was evening and there was morning a $x$ day," is consistently recast as an introductory clause to the paragraph which follows: "And after the evening and morning of the $x$ day passed. . . "14 Polliack suggests that Saadiah's "inclination to alter original elements of the biblical text in response to extra-textual concerns is yet another manifestation of this assimilation, when viewed from a cultural perspective. In this measure Saadiah catered to the concerns of Jews whose religious, intellectual, and aesthetic norms were deeply influenced by the Arab culture and Muslim environment in which they lived." 15 I would agree with this statement but emphasize that cultural considerations were not the only or even the primary motivations for interpretive translations resulting from "extra-textual concerns"; Saadiah's own explanation for these alterations, as expressed in the introduction to his Commentary, seems to me to be more directly relevant in many cases. Additionally, the mere fact that Saadiah was conscious of his audience's assimilation into an Islamic culture does not always

can bc so described). Saadiah also explains that one needs to use interpretive translation to rcconcile contradictory biblical passages, citing the apparent contradiction between Deut 6:16 ("Do not try the Lord your God") and Mal 3:10 ("Put me to the test-said the Lord of Hosts").

${ }^{12}$ Polliack, The Karaite Tradition, p. 276.

${ }^{13}$ Polliack, The Karaite Tradition, pp. 170-173. On Saadiab's usc of cognates in the Tafsir $r$, see below, n. 22.

${ }^{14}$ Polliack discuses this example in a slightly different context; see The Karaite Tradition, p. 112.

${ }^{15}$ Polliack, The Karaite Tradition, p. 276. 
account for why he altered specific original elements of the biblical text as he did.

One feature of the Tafsir has prompted some speculation with regard to Saadiah's intended audience. Saadiah regularly translates biblical names and locations into Arabic even without clear evidence that his translation is accurate. The 12 th-century commentator Abraham Ibn Ezra, who frequently cites and often rejects Saadiah's translational interpretations, comments acerbically that

[Saadiah] did this with families, cities, animals, birds, and rocks. Maybe he saw them in a dream. And he certainly erred in some cases, as I will explain in their proper places. If so, we should not rely on his dreams. Perhaps he did this for the glory of God. Because he translated the Torah in the language of Ishmael and in their script, The translated unknown Hebrew words] so that they will not say that the Torah contains commandments [miswot; in some manuscripts milot,

"words"] which [the Jews] do not understand. ${ }^{16}$

On the basis of this comment, some scholars have argued that Saadiah, breaking with the universal Rabbanite practice of using Hebrew characters, wrote the Tafsir in Arabic script for an Islamic audience. Moshe Zucker, however, forcefully argued that, Ibn Ezra's comment notwithstanding, Saadiah did indeed write the Tafsir in Hebrew script. This argument has been bolstered by the fact that no texts of the Tafsir in Arabic script have been found in any of the Genizah collections. On the contrary, Blau recently discovered an 11 th-century manuscript of the Tafsir written in Hebrew script, which he says is proof that the original work must also have been written in the same manner. ${ }^{17}$ As Muslims at the time could not read Hebrew or Hebrew characters, ${ }^{18}$ this clearly indicates that Saadiah wrote his translation of the Torah with a Jewish audience in mind, an assumption supported by Saadiah's own description of his work.

${ }^{16}$ Abraham Ibn Ezra, Perushei ha-Torah le-Rabbenu Avraham ben Ezra' al pi Kitvei Yad u-Defusim Rishonim, ed. A. Weiser (Jerusalem, 1976), reprinted in Toral Hayyim (Jerusalem, 1986), Gen 2:11. The translation is my own.

${ }^{17}$ M. Zucker, 'Al Targum Rasag la-Torah (New York, 1959), pp. 284-285. On the corroboration of Zucker's argument from genizah sources, see Blau, "Iyyunim," p. 112 and Tobi, "Seridei Targum," p. 113.

${ }^{18}$ E. Ashtor, Toledot ha-Yehudim be-Mitșrayim ve-Suriah tahat Shilton ha-Mamlukim (Jerusalem, 1944), 1:359.
Saadiah, in the introduction to the Tafsir, states that he wrote it

because someone asked me to set apart the plain text of the Torah into a distinct work that would not include any words of philology . . . and would not include any questions of the heretics or the responses to them, nor details of rational law or how to perform traditional law, but rather a publication solely of the meaning of the text of the Torah.

The longer work to which Saadiah alludes here, which includes the Commentary on Genesis, no longer exists in its entirety, although it may have been known to Ibn Ezra and other medieval commentators; it is clear, however, that the Tafsir was intended to serve a different and more limited function. Yet although Saadiah states that his work is intended to reflect "the plain text of the Torah" (basit nass al-tawra), he acknowledges that it is not a literal translation. As he says further on, this work is "solely a translation of the plain text of the Torah, made accurate on the basis of the knowledge of reason and tradition. And if it is possible for me to insert a certain word or letter through which the meaning and intention will be revealed to one for whom an allusion is more satisfactory than a statement, I have done this." ${ }^{19}$ On the basis of this introduction and the gaon's known interests and ideological commitments, modern scholars have ascribed to Saadiah several goals in writing the Tafsir. In addition to his stated objective of providing a clear translation of the plain meaning of the Torah, Saadiah was interested in the education and guidance of the assimilated Jewish masses who no longer understood Hebrew, the reconciliation of the Torah with reason and

\footnotetext{
${ }^{19}$ J. Derenbourg, ed., Tafsir al-Turia [sic| bi'l-'Arabiyya (Paris, 1893), p. 4. This work constitutes the first volume of an unfinished collection of Saadiah's work titled Al-Tafāsìr, al-Kutub, wa'l-Rasā'il (The Tafsìrs, Books, and Letters). Derenbourg provides a Hebrew translation of Saadiah's introduction; this English translation, based on Derenbourg's text of the original, is my own. For a complete English translation in light of a variant manuscript, see Polliack, The Karaite Tradition, pp. 82-84. For a complete Hebrew translation in light of different variant manuscripts, see Zucker, 'Al Targum Rasag, pp. 128-129.

Unless specifically noted, all citations of Saadiah's Tafsir are taken from the Derenbourg edition, despite the widely recognized faults of this work. I have consulted several manuscripts and editions of the Tafsir to confirm the accuracy of those passages that are key to my arguments and have found that, except for one instance, there arc no significant discrepancies among the texts. I discuss that one exception in detail below, p. 374, and mention minor variants in the notes.
} 
rabbinic tradition, and the refutation of heretical and particularly Karaite beliefs. ${ }^{20}$

It is my contention that Saadiah deliberately and selectively relied on Islamic sources in order to advance several of these goals. Saadiah's Tafsir shows evidence of conscious attention by the author to the stylistic expectations of his assimilated audience and of his use of specifically Islamic terms, traditions, and sources to provide more detailed or more rationally acceptable interpretations of certain biblical passages. Islamic influence has been identified in Saadiah's grammatical, philosophical, and exegetical works ${ }^{21}$ so it is not especially

${ }^{20}$ See Zucker, 'Al Targum Rasag, pp. 8-9, 319; Polliack, The Karaite Tradition, p. 22; E. Schlossberg, "Ha-Megamot ha-Hevratiot shel Hiburei Rav Se'adiah Ga'on," Asufot 6 (1992) 71-85

${ }^{21}$ Saadiah's Hcbrcw grammatical treatise, the Agron, shows signs of inspiration and horrowing from Arahic sourccs, which Saadiah himself indirectly credits for prompting his decision to write the work; see Malter, Saadiah Gaon, pp. 39-40. Onc can also clearly see Islamic influence in Saadiah's philosophical works, which contain the same structure, principles, and arguments as contemporary mu'tazili treatises; see H. Hailperin, "Saadia's Relation to Islamic and Christian Thought," Historia Judaica 4 (1942) 2-16, and Zucker, ed., Perushei Rav Se'adiah, p. 19, n. 5. (Mutazilism is a school of Islamic thought that relies heavily on rationalism and borrows from Greck philosophical traditions.)

Saadiah is the first rabbinic commentator to base his biblical interpretation on philological and rational principles, as was standard in qur'anic interpretation of his day. His reliance on the concepts of muhkamāt and mutashäbihāt in his theory of interpretation (see ahove, p. 356) parallcls that of qur'anic exegetes such as al-Tabarī, an important Islamic figure who lived in Baghdad shortly before Saadiah's own time; the terms themselves are found in Qur'an 3:7 (in the Egyptian versification). See Zucker, 'Al Targum Rasag, pp. 234-236; Zucker, ed., Perushei Rav Se'adiah, pp. 35-40; E. Schlossberg, "Rasag: Rav Se'adiah Ga’on Parshan ha-Miqra'," Mahanayim 3 (1993) 76-91. For an analysis of the various approaches taken by Islamic commentators to these terms, see L. Kinberg, "Muhkamāt and Mutashäbihăt (Koran 3/7): Implication of a Koranic Pair of Terms in Medieval Exegesis," Arabica 35 (1988) 143. For a specific instance in which Saadiah may have been influenced by the content of alTabarî's commentary, see below, p. 392.

Eliezer Schlossberg has argued that the exegetical tafsir on Daniel and the Commentary on Genesis contain indirect polemicization against Islam, expressed in Saadiah's complaints about the treatment of Jews under Islam, his refutations of arguments known to be made by Islamic polemicists, and his reinterpretations of biblical verses said to advance Islamic claims. Schlossberg, who wrote his dissertation on the subject of Saadiah's tafsir on Daniel, relies heavily on this work in his argument that the gaon engaged in anti-Islamic polemic; see, for example, E. Schlossberg, "Yahaso shel Rasag le-Islam," Da'at 25 (1990) 21-51. Daniel J. Lasker, who reinterprets many of the works Schlossberg considers to be anti-Islamic as being primarily anti-Christian, surprising to find it in this work of translation as well. There are a handful of scholars who have identified select examples of such influence in the Tafsir, and I have incorporated their arguments into this work. I have arranged the examples that follow so as to begin with those which may be explained largely on the basis of Polliack's thesis of Islamic cultural influence on Saadiah's work, whether unconscious or, more probably, conscious in nature. I then proceed to passages from the Tafsir that can be explained only on the basis of conscious borrowing on the part of the gaon from specifically Islamic sources.

\section{ISLAMIC TERMINOLOGY AND PHRASEOLOGY:} $I M \bar{A} M, R A S \bar{U} L, A N \bar{A} A L L \bar{A} H$

Polliack cites as a point of distinction between Saadiah and his Karaite counterparts the fact that the former frequently uses Islamic religious terms and expressions whereas the latter avoids such terms and prefer to use Arabic cognates of biblical words. ${ }^{22}$ Her primary example is Saadiah's translation of the Hebrew kohen, "priest," as imām. Although the word imām does have the general meaning of "any exemplar" or "leader," it is most strongly associated with its Islamic religious sense of a "person whose example is followed ...

also acknowledges the anti-Islamic nature of the tafsir on Danicl; see, for example, D. J. Lasker, "Neged Mi Hitpalmes Rav Sc'adiyah Gaon be-Diyyuno he-Bițul haTorah?" Da'at 32-33 (1994) 5-II. See also E. Schlossberg, "Ofav u-Megamato ha-Parshanit shel Perush Rav Se'adiah Gaon le-Sefer Daniel," Proceedings of the American Academy of Jewish Research 56 (1990) 5-15 of the Hebrew section, which briefly discusses polemical activity in the Commentary on Genesis as well. Schlossberg does not make much use of the Tafsir of the Torah in this argument, nor does he appear to notice the instances in which Saadiah does not refute but rather adopts Islamic interpretations.

${ }^{22}$ Polliack, The Karaite Tradition, p. 174. Although Polliack may be correct that Saadiah is relatively less likely than Yefet and Yeshu'ah to use cognate words in his translation, Saadiah most certainly does rely on cognates in numerous translations, even when a different Arabic word might be more accurate. This tendency was noted by Zucker, 'Al Targum Rasag, p. 267. To eitc just a few examples drawn from translations cited elsewhere in this work, Saadiah translates tevah (Noah's "ark") as tābüt (box or chest) rather than fulk or safina (boat) (see below, n. 74), the color șahov (yellow) as așhab (blond or light yellow) rather than asfar (see below, p. 390), and me'addamim (reddened, with reference to animal skins) as adim (tanned). 
in prayer." The word also conveys a specifically Islamic connotation, as "leader of the Muslims." 23 The Qur'an refers to Muhammad as the imam par excellence, and Shicis use the term specifically to refer to the holy descendants of the Prophet. Despite the word's Islamic overtones, however, Saadiah has no qualms using it to refer to Aaron and his descendants even though he could have instead used the Arabic word kähin, cognate with the Hebrew kohen. ${ }^{24}$ Presumably, Saadiah preferred imām in part because the word kāhin bears the unwanted connotations of "diviner" or "astrologer." 25 Saadiah's choice of the more appropriate word despite its Islamic connotations reflects the gaon's goal of producing "a target text which is orientated towards the language and culture of the reader," as Polliack suggests, ${ }^{26}$ as well as his lack of concern about using words associated with the dominant religion of his day.

Saadiah's use of Islamic terminology in the Tafsir is quite nuanced at times, as can be seen in his use of the Islamic phrase rasül allāh, "messenger of God," in reference to Moses. ${ }^{27}$ The distinction between the words rasūl and nabi, both of which refer to prophets, is foreign to Hebrew and unknown in talmudic literature. In the Qur'an and Islamic thought, however, the former term is used for an elite subset of prophets, specifically those bearing written revelations. Wilhelm Bacher notes that Saadiah is not the only medieval Jewish figure to refer to Moses as ras $\bar{u} l$ allăh, and that in fact this term was often used in the context of anti-Islamic polemic designed to counter the Islamic contention that Moses was less worthy of divine revelation than Muhammad. ${ }^{28}$ Adolf Schmiedl, however, rejects Bacher's suggestion that the mere reference to Moses as ras $\bar{u} l$ allāh could be polemical, noting that the Qur'an itself recognizes

\footnotetext{
${ }^{2.3}$ E. W. Lane, Arabic-English Lexicon (1863; repr., Cambridgc, 1984), s.v. '.m.

${ }^{24}$ Polliack notes that Karaite translators generally prefer the word $k \bar{a} h i n$, but occasionally use the word imām; see The Karaite Tradition, p. 174. Blau, "Some Instances," p. 22, notes that the translation of kohen as imām is also found in the 10thcentury Karaite works of Hefes b. Yașliah, Qirqisani, and David b. Abraham al-Fasi; Blau attributes this to the influence of Saadiah's Tafsitr on later translators.

${ }^{25}$ See Lane, Arabic-English Lexicon, s.v. '.r.f., who follows al-Jäwhari (Iraq, d. early 11 th century) in associating the word kähin with 'arräf.

${ }^{26}$ Polliack, The Karaite Tradition, p. 260.

${ }^{27}$ Polliack, The Karaite Tradition, p. 174, notes that Yefet and Yeshu'ah refrain from using this phrase.

${ }^{28}$ W. Bacher, "Notizen zu Saadja's Pentateuchübersetzung I," MGWJ 45 (1901) $565-566$.
}

Moses' status as a rasūl allāh (Qur'an 61:5). ${ }^{29}$ Whether or not Saadiah uses this phrase for polemical purposes, it is clear that the gaon is careful in his use of rasül allāh not to contradict in any way the Islamic understanding of the term.

Saadiah's selective use of the term rasül can be seen in his translations of verses in which Moses is referred to as an eved, "servant": the gaon only translates the word "eved in reference to Moses as ras $\bar{u} l$ in contexts that conform to the Islamic conception of a ra$s \bar{u} l$ as a leader of the people and representative of God on earth. At the conclusion of the dramatic depiction of the Children of Israel's escape through the Sea of Reeds and the drowning of the Egyptians, Exod 14:30-31 reports:

Thus the Lord delivered Israel that day from the Egyptians, Israel saw the Egyptians dead on the shore of the sea. And when Israel saw the wondrous power which the Lord had wielded against the Egyptians, the people feared the Lord; they had faith in the Lord and His servant Moses.

The clear focus of this passage is on God's power; the people's faith in Moses is the result of their belief in the might of God. Saadiah therefore translates the end of Exod 14:31 as wa-amanü bi-lläh wabi-Mūsa rasülihi, "they had faith in the Lord and His messenger Moses," reflecting Moses' role as God's apostle or emissary. So too in relating Moses' death, Saadiah highlights this role by translating 'eved $Y H W H$ as rasül alläh (Deut 34:5). In another passage, however, Saadiah twice translates the word 'eved literally, even though it refers to Moses. Numbers 12 recounts the incident in which Aaron and Miriam speak badly about their brother and are taken to task by God for their indiscretion.

And He said, "Hear these My words: When a prophet of the Lord arises among you, I make Myself known to him in a vision, I speak with him in a dream. Not so with My servant Moses; he is trusted

${ }^{29}$ A. Schmiedl, "Randbemerkungen zu Saadja's Pentateuchübersetzung," $M G W J 46$ (1902) 362-363. This is the third and final installment in a series of articles Schmied wrote in MGWJ from 1901-1902 with this title; Bacher's discussion of rasül occurs in his response to the first of Schmiedl's articles. IsIamic tradition accords the status of rasül to numerous prophets, including Moses and Jcsus; it merely asserts that Muharnmad was the last and greatest of these inessengers.

All references to qur'anic passages in this work cite the standard Egyptian versification. 
throughout My household. With him I speak mouth to mouth, plainly and not in riddles, and he beholds the likeness of the Lord. How then did you not shrink from speaking against My servant Moses!" (Num $12: 6-8$ )

The word 'eved is used here as part of an analogy: just as a trusted servant has access to his master's entire household while others do not, so too does Moses possess a closer relationship with God than do other prophets. This passage provides what one could call a biblical counterpart to the qur'anic distinction between a nabi and a ra$s \bar{u} l$, but if Saadiah were to have used the latter term in this context he would have destroyed the analogy that expresses this distinction. Furthermore, the Moses of Numbers 12 is presented not as the great leader of the people and messenger of God, but rather as a humble individual; he is "avdi, "My servant," not 'eved $Y H W H$, "the servant of the Lord." Saadiah, sensitive to the meaning and connotations of the Islamic phrase rasūl allāh, incorporates it into his Tafsìr where it best expresses the force of the biblical Hebrew but offers a more literal translation when the Islamic phrase would be inappropriate.

A similar pattern can be seen in Saadiah's translation of the word ish, "man," when referring to Moses. Deut 33:1, which introduces the final blessings Moses bestows upon the Children of Israel before his death, describes Moses as ish ha-elohim, "the man of God." In translating this phrase as rasūl allāh, Saadiah emphasizes Moses' special relationship with God and the divine source of the blessings which Moses transmits to the people. ${ }^{30}$ Exod 11:3 reads, "The Lord disposed the Egyptians favorably toward the people. Moreover, Moses himself [ha-ish Moshe, literally: the man Moses] was much esteemed in the land of Egypt, among Pharaoh's courtiers and among the people." Saadiah translates ha-ish Moshe as Mūsā alrasül, strengthening the connection between the two halves of this verse and expressing the reason for the Egyptians' high regard for Moses. ${ }^{31}$ Saadiah does not, however, alter his translation of Exod

\footnotetext{
${ }^{30}$ This is one of several modifications Saadiah makes in his translation of the opening lines of Moses' final benediction in order to stress that Moses himself is not the source of the blessings but functions rather as an intermediary able to transmit God's blessings to the people and to intercede beforc God on their behalf.

${ }^{31}$ See Zucker, 'Al Targum Rasag, p. 275, who cites Saadiah's Commentary on this verse. Not all of the manuscripts and editions preserve the same language here. The rendering $M \bar{u} s \bar{a}$ al-rasūl appears in the Derenbourg, Tăj, and Polyglot editions; the
}

32:1 and 32:23, in which the people demand that Aaron make them a god because "that man Moses" had not descended from Mount Sinai. Since Islamic tradition maintains that God always guarantees the success of each rasül, it would have been incongruous for the Children of Israel to acknowledge Moses' apostolic status while expressing fear regarding his whereabouts and demanding a replacement. Rather, the reason for the people's lack of faith was that they considered Moses to be merely a mortal and, despairing of his whereabouts, sought another conduit to $/$ God. ${ }^{32}$ Saadiah's judicious use of the phrase rasül allāh indicates his thorough familiarity with the nuances of this Islamic concept and his interest in incorporating it properly into his translation of the Torah, perhaps in part to ensure that no reader would think that Moses was not a true rasül.

Zucker, who notes the example of ha-ish Moshe but not 'eved $Y H W H$ or kohen, cites several additional occasions on which Saadiah employs expressions taken from Islamic religious literature. ${ }^{33} \mathrm{He}$ associates the gaon's use of the word hall in Exod 12:32, referring to the sacrifices the Israelites were to offer upon leaving Egypt, with the qur'anic passages which prohibit the consumption of meat which has been offered in sacrifice (uhilla) by anyone other than God (Qur'an 2:173, 6:145, 16:116). Saadiah, like JPS, translates Deut 30:6a as "Then the Lord your God will open up your heart . .." even though the text literally reads "circumcise your heart"; the phrase which Saadiah uses, wa-yashrah ... șadraka, appears in Qur'an $6: 125,20: 25$, and 94:1. Zucker also points out the Islamic resonances of other words used by Saadiah, such as the term andād to refer to idols in Lev 26:30, shafa'atu to refer to Moses' intercessionary activity in Deut 9:18 and 9:25, forms of the verb istakhlafa

14th century Yemenite MS JTSA Lutzki 647 contains $M \bar{u} s \bar{a}$ rasūl allāh, more closely approximating the traditional Islamic formula. Both Derenbourg's Yemenite manuscript and MS JTSA 5556 (a 19th century manuscript from Jerusalem in Yemenitc script) translate the phrase literally as $M \bar{u} s \bar{a}$ al-rajl.

32 The word ish is also used to describe Moses in Exod 4:10 ("But Moses said to the Lord, Please, O Lord, I have never been a man of words...") and Num 12:3 ("Now Moses was a very humble man..."). In both of these cases, the Tafsir does not contain a direct parallel to the Hebrew word ish, for reasons unrelated to the gaon's interpretation of these verses.

${ }^{33}$ Zucker, 'Al Targum Rasag, pp. 274-275; I have altered Zucker's qur'anic references to conform to the standard Egyptian versification and added one biblical reference (Deut 6:5) to his list. 
(related to khalifa) to refer to appointed successors in Lev 6:15, Num 27:16, and Deut 31:23, and the word mukhlisan, "faithfully," which Saadiah appends to the command to love God with all of one's heart and soul (Deut 4:29, 6:5, 10:12). ${ }^{34}$

Saadiah uses not only Islamic terms in his Tafsīr, but also Islamic forms of speech. A clear example of this can be seen in his translation of the phrase ani YHWH, "I am the Lord," and its variants. When this phrase is unmodified in the biblical text (e.g., Lev 19:3, 19:18), Saadiah regularly augments it with one of over a dozen adjectival or verbal descriptions of God, such as al-wähid, "the One" (e.g., Lev 19:4), al-mu'āqib, "the Punisher" (e.g., Lev 19:16), and ujāzikum khairan, "I will reward you well" (e.g., Lev 19:10). ${ }^{35}$ When the Torah offers its own descriptions of God, Saadiah frequently rearranges the sentence structure so that the description immediately follows the phrase ana allāh; so, for example, Saadiah renders the conclusion of Lev 19:2, ki qadosh ani YHWH eloheikhem, as la-anni alläh rabbukum al-quddūs, as if the Hebrew read ki ani YHWH eloheikhem ha-qadosh. ${ }^{36}$ As a result of Saadiah's modifications, nearly every occurrence of the phrase ana allāh in the Tafsir is followed immediately by a description of God or of God's actions, whether such a description appeared in the original verse, was relocated from elsewhere in the original verse, or was inserted by Saadiah himself. ${ }^{37}$ Yehudah Ratzaby has identified three instances in which rab-

${ }^{34}$ Wilhelm Bacher, in Abraham Ibn Esra's Einleitung zu seinem Pentateuch-Commentar (Vienna, 1876), p. 34, notes that Saadiah's translation of Psalms uses Islamic terminology for the words "priest," "king," and "ministcr" (imām, khalifa, and wazir. respcctively). I have not found the last of these terms employed in the Tafsir of the Torah. Saadiah does use the word sultan and other forms of this root (e.g., Gen 42:6), but I would not ascribe this to Islamic influence, in part because the root is cognate with the Hebrew shalit, which appears in the biblical text. Furthermorc, the Arabic term sultan is known to have taken on the specific connotation of a political leade only in the decades after Saadiah's death, and it does not connote any sense of religious authority. See J. H. Kramers, "Sultān," Encyclopaedia of Islam, 2nd ed., 9:849-853.

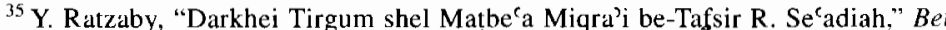
Miqra 41 (1995-1996) 249-252, presents two versions of a list of these modifications. Unfortunately, both lists are incomplete and contain inaccurate references.

${ }^{36} \mathrm{JPS}$ renders this clause in the same way that Saadiah does: "for I, the Lord your God, am holy." Saadiah appends the descriptive adjective al-quddüs to the conclusion of Lev 20:7 as well.

${ }^{37}$ Of the eighty-five occurrences of a phrase related to ani $Y H W H$ in the Bible, Saadiah augments forty-five and modifies the sentence structure of ten; twenty instances binic sources add a description of God to the phrase ani YHWH, but he is otherwise unable to account for why Saadiah feels compelled to make these modifications. ${ }^{38}$

This pattern strikes me as being modeled after well-known Islamic phrases. Throughout the Qur'an, references to God are followed by descriptive adjectives; the most prominent example is the basmala, the phrase introducing nearly every süra, which is commonly translated as "In the name of God, the Merciful, the Compassionate." The basmala became the standard opening of written texts and ritual activities during the earliest years of Islam and would undoubtedly have been familiar to all who lived in the Islamic world One can reasonably infer that Saadiah's practice of appending descriptive adjectives to God's name stems in no small measure from the parallel Islamic practice. Yet Saadiah does not feel bound by the specific descriptions of God found in Islamic texts. Although alquddūs and al-wăhid both appear in the Qur'an, the remainder of Saadiah's descriptions do not, and Saadiah never uses the most common qur'anic epithets-al-rahmān al-rahim from the basmala-presumably for the simple reason that they do not fit well into the context of the biblical ani $Y H W H$ passages. Saadiah uses specific Islamic words and a particularly Islamic literary style because he considers them to be accurate, or useful for his purposes, or simply most suitable for an assimilated Jewish audience. He does not, however, engage in wholesale copying merely to create parallels between the Qur'an and his Tafsir.

required no modifications to fit Saadiah's pattern. (These numbers come from an analysis of Derenbourg's edition and include two instances of auginentation that appear in manuscripts consulted by Derenbourg but do not appear in his primary text.) Of the ten remaining phrases, five come in the context of statements proving God's existence and thrce introduce declarative statements made by God; neither structure lends itself to Saadiah's pattern, so the gaon did not modify these verses. On two occasions (Lev 18:2, 26:44), Saadiah seems to be content with the biblical eloheikhem/ eloheihem (your/their God) as a sufficiently appropriate description of God, cven though in other contexts he feels the need to supplement these words with his own descriptions.

${ }^{38}$ Ratzaby, "Darkhei Tirgum," pp. 249-250. Onkelos and Pseudo-Jonathan each modify this phrase once (in Exod 8:18 and Lev 20:7, respectively), and Sifra contains an interpretation of Lev 19:37 that supplies an addition to the base ani YHWH. Saadiah adopts these modifications in his own translations of these verses. 
All of these examples of Islamic influence on the Tafsir can reasonably be explained in light of Polliack's theory of cultural influence. Saadiah certainly would not have needed to rely on the Qur'an to be familiar with the Islamic practice of appending descriptive adjectives to the name of God or to understand the connotations of terms such as rasül. Zucker's assertion that the gaon makes use of several less universally known Islamic terms and phrases may be a stronger indication that Saadiah was directly reliant on specifically Islamic sources, but not every similarity in word choice indicates borrowing. For example, Saadiah's Tafsir and the Qur'an both use the same words for manna, quail, and calf, but this is presumably because there is only one good Arabic word for each of these terms. Yet the particularly Islamic nature of some, if not all, of the parallels discussed above becomes more evident once one recognizes that Saadiah does indeed consciously borrow from Islamic sources in other instances. Evidence to support this assertion will be discussed below; first, however, we turn to another example of Islamic influence that can be attributed to Saadiah's cultural environment.

\section{ISLAMIC LAW: TEMPORARY MARRIAGES}

Saadiah frequently translates biblical passages to conform to rabbinic law, including his translation of the verses about boiling a kid in its mother's milk cited above. Zucker cites almost 350 examples of such translations (most not nearly as obvious), as well as fortyfive instances in which the Tafsir contradicts midrash halakhah ${ }^{39}$ Among these latter cases is an intriguing verse in which Saadiah not only contradicts rabbinic law but also specifically rejects a practice debated within Islamic law. That practice is known as mut' $a$, which the Encyclopaedia of Islam defines as 'literally, 'enjoyment,' used in Islamic law in the sense of temporary marriage (according to the Arab lexicographers 'marriage of pleasure'), a marriage which is contracted for a fixed period on rewarding the woman." The Qur'an itself may have permitted $m u t^{\prime} a$ and the practice remains legal to this day among Shi'is, but by the 9 th century $\mathrm{CE}^{-}$the practice had been prohibited within Sunni circles. Mordechai Friedman cites

\footnotetext{
${ }^{39}$ On verses that conform to rabbinic law, see Zucker, 'Al Targum Rasag, pp. 320 441 ; on verses that do not, see pp. 442-479.
}

sources indicating that, despite this prohibition, $m u t^{\prime} a$ in all but name nevertheless continued to be practiced by Sunnis. ${ }^{40}$

Saadiah expresses his disapproval of $m u t^{\prime} a$ by translating the biblical word qadesh (f. qedeshah), which JPS translates as "cult prostitute," as mumta' (f. mumta' $a$ ), one who enters into a temporary marriage. Thus, Deut 23:18 ("No Israelite woman shall be a cult prostitute, nor shall any Israelite man be a cult prostitute") turns into a prohibition against mut' $a$. The term qadesh has been given a range of meanings by rabbinic interpreters-Onkelos translates it as "servant," Sifrei and Pseudo-Jonathan (along with Rashi and Rambam) as "harlot," R. Ishmael as "a partner in beastiality" (bSan 54b)—but Zucker cannot find any rabbinic support for Saadiah's interpretation. On the contrary, the Talmud seems explicitly to permit temporary marriage, and recounts that Babylonian rabbis of great stature engaged in the practice. ${ }^{41}$

${ }^{40}$ W. Heffening, "Mut'a," Encyclopaedia of Islam, 2nd ed., 7:757-759; M. A. Friedman, "Ha-Halakhah ke-'Edut le-Hayyei ha-Min eșel ha-Yehudim shebe-Arșot ha-Islam bi-Yemei ha-Beinayim: Kisui ha-Panim ve-Nisu'ei 'Mut'ah'," Pe'amim 45 (1990) $100,103$.

${ }^{41}$ Zucker, 'Al Targum Rasag, p. 478; see also Friedman, "Ha-Halakhah ke-'Edut," p. 102. bNed 29a and pQid 3.1 both require a get for women who wcre betrothed for limited times, and PQid 3.1 specifies that the qiddushin is valid. $M u t^{c} a$ marriages in Shi' $i$ law do not require a bill of divorce, but Zucker and Fricdman suggest that Saadiah must be prohibiting even a temporary marriage concluded by a get, because otherwisc the objection to the marriage would be on the more serious grounds that the woman's subsequent "husbands" would effectively be committing adultcry.

According to bYom $18 \mathrm{~b}$ and bYeb 37b, "Rab, when he went to Dardeshir [according to Yoma: Darshish], called out, 'Who will be my [wife] for a day?' Also R. Nahman, when he went to Shekhansib, called out, "Who will be my [wife] for a day?", The Babylonian Talmud in these passages prohibits the practice of marrying wives in multiplc locations for fear that the children of the two wives might unknowingly marry one another, but considers it permissible for rabbis, because they are important enough individuals that the mothers would be sure to tell their children the nature of their paternity. (The question of whether a get is necessary docs not seen to be an issue here.) Although the Talmud does prohibit temporary marriages among commoners, it does not do so on the same grounds as Saadiah docs. It is noteworthy that both instances of temporary marriage occur in Sassanid Babylonia, as scholars of Islam have conjectured that mut $^{\prime} a$ marriage rentained permissible in Shici Islam because it was an accepted practicc in the Persian socicties that came to form the backbone of Shicism; see B. Hjcrrild, "Islamic Law and Sasanian Law," in Law and the Islamic World Past and Present, eds. C. Toll and J. Skovgaard-Petersen (Copenhagen, 1995), pp. 49-55. 
Although Saadiah effectively creates an unprecedented biblical prohibition against temporary marriage, he considers it to be a lesser offense than other improper sexual relationships. The gaon explains the prohibition against mut' $a$ in his Commentary on Exodus, 20:13.

And the Seventh Commandment, "Do not commit adultery": In it there are seven senses [in ascending order of severity] beeause there are seven categories of people with whom illicit relationships are forbidden. The first is the $m u t^{\prime} a$ marriage, because a woman who does this is called a qedeshah as you learn from the story of Tamar. And [the Torah] prohibits this, and says, "No Israelite woman shall be a qedeshah, and no Israelite man shall be a qadesh"; both men and women are prohibited [from engaging in such relationships]. . . ${ }^{42}$

Saadiah's interpretation of the relationship between Judah and Tamar as a mut' $a$ marriage is ingenious. The advantage of $m u t^{\prime} a$ marriage over mere harlotry (to the extent that one recognizes a legal distinction between the two) is that the relationship is legitimate and therefore all offspring produced in that relationship are the legal heirs of the father. In the biblical account, Judah does in fact accept the legitimacy of his sons by Tamar, one of whom is the forebearer of King David. In the process of identifying Tamar as a woman interested in a temporary marriage, Saadiah also partially exonerates Judah, whom the Bible portrays as freely sleeping with harlots but whom the gaon considers to be guilty only of the least illicit form of improper sexual relationships. Saadiah asserts that the context of the encounter between Judah and Tamar proves that the word qedeshah means "one who is in a temporary marriage"; this practice is later expressly forbidden by Deut 23:18.

It is possible that Saadiah actually believed that the word qedeshah means mumta' $a$ on the basis of its use in Genesis 38, but this strikes me as highly unlikely. In that chapter, the word qedeshah is used only by Judah's friend, describing the woman with whom Judah slept (Gen 38:21-22); Judah himself considers the woman to be a zonah, a harlot (Gen 38:15). Saadiah, however, uses the word mumta' $a$ in all three of these verses, even though.he translates the

${ }^{42}$ Zucker, 'Al Targum Rasag, p. 478, and Friedman, "Ha-Halakhah ke-`Edut," pp. 100-101, both provide this text in its original along with a Hehrew translation. This English translation, based on the Judeo-Arabic, is my own. With the exception of the word $m u t^{c} a$, italics signify words that Saadiah wrote in Hebrew, not Arabic.
Hebrew root z.n.h. with its Arabic equivalent in Gen 38:24, when Tamar is accused of harlotry. Saadiah's "mistranslation" in Gen 38:15 masks the biblical evidence that contradicts his argument, but the gaon himself was surely aware of this contradiction. Furthermore, a plural form of the Hebrew, qedeshim, appears in Job 36:14, where Saadiah translates it as majāna, a word whose meaning is closely parallel to the JPS translation "depraved," and which has nothing to do with temporary marriage. ${ }^{43}$ Nevertheless, Saadiah uses the opportunity afforded him as a translator and interpreter of the Torah to insert surreptitiously his own legal lesson about an Islamic practice into the biblical text.

Why did Saadiah bother to do so, and why did he take a position contrary to that expressed in the Talmud? Friedman suggests that Saadiah (like his Karaite counterparts who addressed the subject in other contexts) was trying to counter a real or perceived threat that Jews would take advantage of the Islamic practice of temporary marriage as a legalized form of harlotry, a practice which the Jewish leadership of the time considered to be an abomination. ${ }^{44}$ The extent to which this threat was real is debatable: only under Shici law is there a distinction between $m u t^{\iota} a$ and harlotry, and even in regions controlled by Shici regimes in the 9 th and 10th centuries the vast majority of local government officials were Sunni (or, in Jewish communities, Jewish) and would therefore not have been sympathetic toward those who claimed that they were "temporarily married." 45 And as Friedman points out, Sunnis had found a way around their own prohibition of mut' $a$, which enterprising Jews could also have used. A more relevant issue in this context is that Friedman takes as a given the fact that Saadiah considered such marriages to be abominable. This appears to be the case, but why would the gaon

${ }^{43}$ See W. Bacher, ed., Sefer Iyyov u-Seraho (Paris, ca. 1899); this work is listed as Volume 5 of Al-Tafäsir, al-Kutub, wal-Rasä'il, although not all of the earlier volumes were published. According to Ch. Pellat, "Mudjūn," Encyclopaedia of Islam, 2nd ed., $7: 304$, this word "can mean the most shameless debauchery, including vulgarity, coarseness, impudence, libertinage, obscenity and everything that may provoke coarse laughter, such as scatological humor." I am grateful to Phillip Kenncdy of New York University for his assistance in tracking down the meaning of this word, which many classical lexica consider too improper to include.

${ }^{44}$ Friedman, "Ha-Halakhah ke-'Edut," p. 103.

${ }^{45}$ I am grateful to Richard Bulliet of Columbia University for his insights on this subject. 
feel this way, especially in light of the Talmud's apparently nonchalant attitude toward the subject? I would suggest that Polliack's theory of cultural influence explains Saadiah's statements regarding $m^{\prime} t^{\prime} a$. Saadiah lived in an environment dominated by Sunni norms and therefore internalized the strong Sunni condemnation of the practice of temporary marriage. Whether Saadiah chose to address the issue of $m u t^{<} a$ in his Tafsir because of concern regarding Jewish sexual activity, because he wanted to undermine a talmudic precedent he found distasteful, or simply because he wished to root his culturally derived opinion in biblical prooftexts, the manner in which he addresses the issue illustrates the culturally mediated influence not merely of Islam in general but Sunni Islam in particular on the gaon and on his biblical translation.

To this point, all of the examples of Islamic influence on Saadiah's Tafsir of the Torah can be explained in light of Polliack's theory that the gaon was attentive to the language and culture with which his assimilated Jewish audience was familiar. There are a handful of instances, however, in which this theory does not adequately account for the apparent borrowing found in the Tafsir. In some cases, Saadiah seems to rely directly on Islamic sources for specific pieces of information that he is unlikely to have learned simply by living in an Islamic environment, or that he is unlikely to have included in this translation simply because they were well known by his audience. We will begin with an apparent case of Saadiah's use of an Islamic tradition, and then proceed to several instances of apparent qur'anic borrowing.

\section{ISLAMIC TRADITION: THE ROAD TO SHUR}

We have already encountered Saadiah's penchant for translating geographic locations in the Bible with or without rabbinic evidence for his cartographic decisions, a practice criticized by Ibn Ezra. Generally, however, the gaon is consistent in such translations, as he is in translating most biblical words; when Saadiah is inconsistent, such as in his translation of zonah as mumta $a$ in Gen $38: 15$, there is often an identifiable reason behind his decision. One particularly egregious example of creative and inconsistent cartography is Saadiah's translation of the place named Shur. According to Exod 15:22, Shur is the desert on the west side of the Sea of Reeds, in which the Children of Israel wandered for three days without water. Shur is also mentioned in Gen 16:7, 20:1, and 25:18, in all three cases as a point of reference used in describing the location of another place. In Gen 16:7, the angel of God meets Hagar and announces the birth of Ishmael at a well on the road to Shur. Gen 20:1 states that Abraham went to Gerar, located between Kadesh and Shur, and Gen 25:18 reports that the children of Ishmael dwelt "from Havilah, by Shur, which is close to Egypt, all the way to Ashur." It seems reasonable, given these four verses, to place Shur within the Sinai peninsula near Egypt. ${ }^{46}$ Both Onkelos and Pseudo-Jonathan consistently translate Shur as hagra, an Aramaic word related to the Arabic hajr, "rock." 47

Saadiah translates the location Shur in no fewer than three different ways over the course of these four verses. In Exod 15:22, he translates the Hebrew midbar shur as bariat shür, both of which simply mean "the desert of Shur." Saadiah renders Shur in Gen 20:1 and 25:8 as al-jifãr. The Arabic geographer Yãqūt (d. $1229 \mathrm{CE}$ ) identifies several places named al-jifār, including a land associated with the Children of Israel that is a seven-day journey from Palestine toward Egypt, in which there is white sand and only bitter water. ${ }^{48}$ This certainly seems to correspond with the presumed location of the biblical Shur, and it is unclear why Saadiah would not have translated Exod 15:22 as al-jifār as well. Most important in the present context, however, is Saadiah's translation of shur in Gen 16:7, which he renders as hajr al-hijäz. "The Rock of the Hijaz," a name derived at least in part from Onkelos' (and Pseudo-Jonathan's?) Aramaic translation of Shur as hagra, can be none other than the Black Rock of

${ }^{46}$ This conclusion is further supported by the two remaining biblical references to the location named Shur, I Sam 15:7 and 27:8, both of which state that the place is close to Egypt.

${ }^{47}$ All citations of Onkelos in this work are taken from the edition prepared by J. Qafih and printed in Torat Hayyim (Jerusalem, 1986). It is possible that Onkelos selected this translation due to the fact that the word shur also means "wall." The Brown-Driver-Briggs Hebrew and English Lexicon (1906; repr., Pcabody, Mass., 1997), s.v. $\breve{s} . w . r$. , which offers this definition, also notes the possible connection between the place named Shur and a line of fortresses along the Suez. M. Jastrow, A Dictionary of the Targumim, The Talmud Babli and Yerushalmi, and the Midrashic Literature (1886-1890; repr., New York, 1996), s.v. hagra, notes that the word is used in tSheb 4.11 to refer to the town of Petra. Jastrow, somewhat unhelpfully, states that hagra as used by Onkelos is a place in the desert of Shur.

${ }^{48}$ Yāqūt al-Hamawi, Múcjam al-Buldān (Beirut, 1955), s.v. jifär. 
the Ka'bah in Mecca. ${ }^{49}$ Saadiah's Tafsir of Gen 16:7 thus ignores all biblical evidence that Shur is in the Sinai and reports that Hagar received the annunciation of the birth of Ishmael on the road to Mecca, the very location to which, according to Islamic tradition, Abraham took Ishmael and Hagar after Sarah sent them away and the place in which Abraham built the Ka'bah. ${ }^{50}$

There can be no doubt that the translation of shur as hajr alhijāz must be due to the influence of Islamic traditions, as Jewish sources ascribe no significance whatsoever to the Hijaz region of Arabia. There are, however, enough manuscript variations regarding this phrase to warrant consideration of the question, did Saadiah really write the words fi tariq hajr al-hijäz, "on the road of the Rock of the Hijaz"? Of the six manuscripts and editions containing Gen 16:7 which I have been able to compare, only the Derenbourg edition (based on the Constantinople edition) contains these specific words. The London Polyglot, which has numerous spelling mistakes due to its transcription from Hebrew script into Arabic script, contains the same phrase except that hajr is misspelled as hajz due to the orthographic similarity between the Arabic $r$ and $z$. MS JTSA Lutzki 647, a 14th-century Yemenite text, omits the word hajr entirely, leaving fi tariq al-hijaz, "on the road of the Hijaz." ${ }^{51}$ The printed edition of the $T \bar{a} j$, the standard Yemenite text of the Tafsir, contains no reference to Mecca as it omits the final word; the resulting phrase, fi tariq hair, conforms more closely to Onkelos' translation. ${ }^{52}$ MS JTSA 5556, a 19th-century text from Jerusalem written

${ }^{49}$ Lane, Arabic-English Lexicon, s.v. h.j.r., notes that al-hajr refers to the stone of the Kabah, while al-hijr means the sacred area encompassing the Ka'bah. According to Yāqūt, the rock of the $\mathrm{Ka}^{\mathrm{C}}$ bah itself is called al-hijr (Yāqūt, $M u^{\mathrm{r} j a m}$ al-Buldān s.v. h.j.r.). Since Saidiah's Tafsir is unvocalized, either pronunciation is possible, but alhajr seems more likely if Saadiah is indecd basing his interpretation on Onkelos' Aramaic. The Hijaz is the region of the Arabian Peninsula in which Mecca and Medina are located

${ }^{50}$ For an analysis of Islamic versions of the Abraham-Ishmael myth, sec R. Firestone, Journeys in Holy Lands: The Evolution of the Abraham-Ishmael Legends in Islamic Exegesis (Albany, 1990); on the subject of the expulsion of Hagar and Ishmael and associated events in Mecca, see espccially pp. 61-103.

${ }^{51}$ Actually, one can only say that the word is most likely to be al-hijäz; because the last lctter of the word is unclear in the manuscript, another possible albeit nonsensical reading would be al-hijāj.

${ }^{52}$ Sefer Keter Torah: Ha-Taj Ha-Gadol, eds. J. A. Hasid and S. Sinai (Jerusalem, 1960), Gen 16:7 in Yemenite handwriting, seems to base itself on the source for the printed $T \bar{a} j$ but renders tari $q$ hajr as tariq hagar, "the road of Hagar." 53 The Yemenite manuscript which Derenbourg himself consulted in the preparation of his edition replaces the problematic phrase entirely with the words fi tariq al-jifär, bringing Gen 16:7 into conformity with Gen 20:1 and 25:18.

Unfortunately, Saadiah's own commentary on this verse is silent on the matter at hand, ${ }^{54}$ so there is no way of proving definitively what Saadiah intended without access to the earliest manuscripts of the Tafsir. It is reasonable, however, to conclude on the basis of the information surveyed above that the Derenbourg-Constantinople version is the most accurate. One can consider the Polyglot, MS 647, and $T \bar{a} j$ variants, as well as the manuscript variant cited by Derenbourg, as being conscious or accidental modifications of the phrase fi tariq hajr al-hijāz; hypothesizing that the Tāj text best reflects the original, one can only account directly for the DerenbourgConstantinople and MS 5556 variants. ${ }^{55}$ Furthermore, it seems much more likely that Judeo-Arabic copyists would endeavor to remove an obvious Islamic reference rather than to include one that had not existed in the original. Still more support for the argument that Saadiah himself chose to refer to the Hijaz region in his Tafsir can be found in his rendering of Gen 10:30 (a verse without complicating textual variants), in which he translates the locations Mesha and Sephar as Mecca and Medina, respectively; Saadiah was clearly not

${ }^{53}$ Both the Hasid/Sinai cdition of the Tăj and MS JTSA $5556 \mathrm{cmploy}$ a particular Judeo-Arabic orthography in which the Arabic letter jim is rendered as a gimmel without a diacritical mark; in the more widespread Judeo-Arahic orthography, a gimme without a diacritical mark would represent the Arabic letter ghavn. If the source for the tariq hagar variant relied on an earlicr text of the Tâj that also used this particular orthography, then the variant can bc cxplained simply as the result of a shift between the orthographically similar Hebrew letters het and heh. (Most personal names in the Tafsir are rendercd in Hebrew, not Arabic; consequently, Hagar's name should not bc read either as hajar or haghar.) On the use of diacritical marks in Judeo-Arabic, see J. Blau, Diqduq ha-'Aravit-ha-Yehudit (Jerusalcm, 1961), pp. 46-47.

${ }^{54}$ See Zucker, ed.. Perushei Rav Se'adiah, 16:7. Saadiah addresses such issues as the status of Hagar and the nature of her conversation with the angel, but not the location of this encounter.

${ }^{55}$ Derenbourg's Yemenite manuscript variant (fi tariq al-jifär) can best be explained as a conseious alteration by a copyist interested in removing a problematic original text. If so, it is more likely based on a manuscript containing a clear Islamic reference rather than one that merely mimics Onkelos. 
averse to including references to Islamic sites in the Tafsir. And Saadiah is not the only rabbinic figure to associate Hagar's flight with Mecca: Ibn Ezra, who frequently relies on Saadiah's interpretations but does not indicate such reliance in this instance, identifies the spring at which the angel meets Hagar as being associated with the Islamic pilgrimage. ${ }^{56}$ Ibn Ezra's interpretation (which does not account for the geographic incongruity of Hagar being at a spring outside Mecca while on the road to the Sinai) does not directly contradict the biblical text; Saadiah, in contrast, is apparently willing to set aside the evident meaning of Gen 16:7 in favor of a tradition drawn from Islam.

Why is the gaon willing to do so? Polliack's theory that Saadiah was influenced by his Islamic cultural environment does not account for his willingness to make this alteration, even if one argues that Saadiah became exposed to the Islamic tradition of Hagar going to Mecca because that tradition had become a part of popular culture. Saadiah was surely exposed to numerous Islamic traditions to which he does not refer in the Tafsir. Since Saadiah himself offers no explanation for this translation, however, we will have to decipher his motivations in light of other passages from the Tafsir that show evidence of borrowing from Islamic texts and traditions. Therefore, instead of offering an answer to this important question now, we turn instead to the first of three occasions in which Saadiah appears to modify biblical texts on the basis of parallel passages in the Qur'an.

\section{QUR'ANIC PARALLEL I: BECOMING LIKE ANGELS}

Translators have long had difficulty with Gen 3:5. The snake, explaining to the woman later called Eve why God does not want her and her husband to eat from the fruit of the tree in the middle of the garden, states that as a result of eating the fruit their eyes will be opened wi-hyitem ke-elohim yod'ei tov wa-ra'. JPS translates the

${ }^{56}$ Ibn Ezra, commenting on the name Hagar gives the spring in Gen 16:14, be er lahai ro' $i$, states that "every year the Ishmaelites celebrate at this well, and to this day the well is called zamum (according to the Paris manuscript noted in the footnotes of the Weiser cdition: zamzav)." Ibn Ezra is presumably reforring here to the well called Zamzam, located just outside Mecca and associated with the annual hajj ritual. According to Islamic tradition, this spring was discovered with angelie assistance by Hagar and Ishmael in their thirst after having been abandoned by Abraham; see Firestone, Journeys in Holy Lands, pp. 63-71. concluding phrase of Gen 3:5 as "you will be like divine beings who know good and bad" with a note, "Others "[you will be like] God, who knows." "The beginning of Gen 6:2, wa-yir'u benei ha-elohim et benot ha-adam ki tovot hennah, offers similar difficulties; JPS renders this portion of the verse as "the divine beings saw how beautiful the daughters of men were" and offers the note, "Others "the sons of God." The trouble with both Gen 3:5 and 6:2 is the word elohim, which most often means "God," as it does at the beginning of Gen 3:5 itself, which JPS renders as "but God knows that as soon as you eat of it [the fruit] your eyes will be opened. ..." The word can also mean "gods" in a polytheistic sense, as in Exod 20:3 ("You shall have no other gods besides Me"), or, according to the rabbis, a human "judge," as in Exod 21:6. None of these meanings, however, would have been acceptable to Saadiah or his rabbinic predecessors in the context of Gen 3:5; the first two options would be rejected on theological grounds-humans cannot become like either God or gods!- - while the third possibility is simply illogical.

Gen 3:5 is quoted infrequently in talmudic and early midrashic literature, so it is difficult to determine exactly how Saadiah's rabbinic predecessors understood it. When cited, the relevant portion of Gen 3:5 is used as an example of a biblical passage in which elohim does not refer to God (Soferim 4.4, NumR 14.12), but neither rabbinic text offers a better translation for the biblical word. The reference to benei ha-elohim in Gen 6:2, however, is subject to a clear rabbinic re-interpretation: "R. Shimon b. Yohai reads it as 'sons of judges' (benei dayyanaya); R. Shimon b. Yohai would curse anyone who read it as 'sons of gods' (benei elahaya)" (GenR 26.5). This interpretation seems to be the standard rabbinic manner of understanding Gen 6:2, and appears without comment in paraphrases of this verse in other rabbinic works. ${ }^{57}$ Onkelos relies on a similar interpretation, translating elohim in both $3: 5$ and $6: 2$ as ravrevin, "great men." This understanding of the word is also reflected in the fragment of a pre-Saadianic Arabic translation of the Torah

${ }^{57}$ See, for example, Sifre, Beha'alotekha 86 . The sharp rabbinic reaction to a literal interpretation of the account in Genesis 6 may well be a responsc to Iewish mystical and apocalyptic traditions that identify the benei ha-elohim with fallen angels (see 1 Enoch 6 and following). If so, it is noteworthy that the reaction is attributed to Shimon b. Yohai, traditionally portrayed as a rather mystical figure himself. 
published by Yosef Tobi, which renders the conclusion of 3.5 as watakūnū ka'l-ashr[äf] 'ärîfi al-khair wa-[l-sharr]. ${ }^{58}$

Saadiah himself follows Onkelos' lead in translating Gen 6:2, which he renders ra'aw banū al-ashrāf banāt al-'ämma, "the sons of the nobles saw the daughters of the commoners."59 Yet Saadiah offers a different interpretation of the word elohim in his translation of Gen 3:5, the conclusion of which he renders wa-tasirän ka'lmalä'ika 'ärifin al-khayr wa'l-sharr, "and you will become like angels, knowing good and evil." ${ }^{60}$ Saadiah thus deviates from Onkelos' translation of elohim as great men, even though he accepts that interpretation elsewhere. Saadiah's reading of this verse has no talmudic parallels, ${ }^{61}$ nor does he appear to be borrowing from

\footnotetext{
${ }^{58}$ Tobi, "Seridei Targum 'Aravi," p. 119.

${ }^{59}$ See also Gen 33:10, in which elohim refers to Esau; Onkelos translates the word as ravrevin and Saadiah renders it al-ashräf. Saadiah offers a different translation of benei ha-elohim in Job 1:6 and 2:1, concerned primarily with the word "sons" rather than "God." There, he renders the phrase as awliyä' alläh, "close associates of God," explaining that the connotation of "sons" here is similar to that found in Deut 14 : ("You are children of the Lord your God"), Exod 4:22 ("Israel is My first-born son"), and Deut 32:5 ( $10^{\prime}$ banav mumam; JPS offers an interpretive translation of this difficult verse), none of which are to be understood literally. See Bacher, ed., Sefer Iyyov $u$-Seraho, 1:6. Saadiah uses the word awliya $\bar{a}^{\prime}$ in his translations of the Deuteronomy passages, and modifies Exod 4:22 so as to make clear that God's statenient regarding Israel's ancestry is meanl to express the honor of Israel.

${ }^{60}$ This according to the Constantinople cdition as printed by Derenbourg. While all manuscripts and cditions of the Tafsir that I consulted agree that the word elohim is translated as malā' $i k a$, there is some discrepancy over the translation of the preceding verb. Derenbourg and the London Polyglot both render the verb tasirän, the dual form of "to become," while two Ycmenite manuscripts in the library of the Jewish Theological Seminary (Lutzki 647 and JTSA 5556) contain the plural form, tasiru. The Tāj (eds. Hasid and Sinai) contains the phrase wa-takūnu $k a^{\prime} l-m a l \bar{a}^{\prime} i k a$ " "and you (plural, not dual) will be like angels." Zucker, in his discussion of manuscript variants of this verse ('Al Targum Rasag, pp. 295-296), notes that Lagarde's edition of the text of Genesis and Exodus replaces ka'l-mala'sika with ka'l-aläha; Zucker rejects this variant on the grounds that Saadiah only uses the words allāh and $r a b b$ to refer to the name of God. Zucker does not address the possibility that Saadiah's use of the word malā'ika in this context derives from Islamic influence. He is much more interested in the possibility (which he accepts) that Saadiah appends the word bi-zi'ada to the end of this verse in order to indicate that eating the fruit would make Adam and Eve more knowledgeable of good and evil; in his Commentary on this verse Saadiah insists that they possessed knowledgc prior to eating.

${ }^{61}$ There is one instance in the Talmud in which the biblical word elohim is understood to mean angcl. It occurs, however, in a different context, namely an interpreta-
} tion of Gen 32:29, ki sarila 'im elohim, which is rendered "Jacob became a master to the Jewish mystical tradition which equates the benei ha-elohim in Gen 6:2 with fallen angels (see 1 Enoch 6 and following), because in that context Saadiah is careful to utilize Onkelos' interpretation of the text. The association between eating from the tree and becoming like angels-which does not appear in talmudic, midrashic, or early Jewish mystical texts-is found instead in Qur'an 7:20, in which Satan asserts that, by eating from the tree, takūna malakayn aw takūnā min al-khālidīn, "you will be angels or you will be among the immortal." 62

Is Saadiah's translation of Gen 3:5 an adoption of the qur'anic understanding of what happened in the Garden of Eden? This seems to be a reasonable possibility, but there are other explanations that must be considered. Saadiah may have borrowed the translation of elohim as angels from Targum Pseudo-Jonathan, a 7th- or 8th-century Aramaic translation of the Torah (also known as the Jerusalem Targum) that, according to some modern scholars, influenced Saadiah's Tafsir. ${ }^{63}$ Although Pseudo-Jonathan's translation of Gen 6:2 parallels Onkelos (benei ravrevaya, sons of great men), the later Targum renders the relevant portion of Gen 3:5 as "wa-tehewon ka-malakhin ravrevin," "and you will be as great angels." Pseudo-Jonathan's version of this phrase effectively combines the text found in the earlier Targum Onkelos and the later Tafsir of Saadiah, with the word

the angel" (bHul 92a). Saadiah translates the word elohim in that verse to mean God, not an angel.

${ }^{62}$ The myth of the tree also appears in Qur'an 2:35-36, 20:120, but without direct reference to angels. According to 20:120, Satan entices Adam to eat from the Tree of Immortality (shajarat al-khuld). 2:35-36 contains no reference to the promiscd outcome of eating the fruit of the tree. Both of these passages, howcver, come in the context of myths about angels: $2: 30-33$ recounts the angelic opposition to the creation of Adam, while both 2:34 and 20:116 tell of God's command to the angels to bow before Adam and Iblis' refusal to do so. Islamic tradition identifies Iblis as Satan.

${ }^{6.3}$ The editors of the Encyclopaedia Judaica note that Saadiah's translation of biblical names is in keeping with Pseudo-Jonathan: see "Saadiah Gaon: Saadiah's Translation of the Bible," EJ 14:553. Derenbourg compares Saadiah's translation with Targum Pseudo-Jonathan on several occasions, including Num 16:3, 18:16. Although Derenbourg does not note comparisons with this translation anywhere in the book of Genesis, it is possible that Saadiah knew Pseudo-Jonathan to Genesis and that it influenced his own work. Several scholars have lamented the numerous deficiencics of Derenbourg's edition; another of these deficiencies may be his inconsistency in comparing Saadiah with Pseudo-Jonathan. 
ravrevin serving as an adjective describing the angels rather than a substantive implicitly referring to human beings. It is possible that Saadiah followed Pseudo-Jonathan's translation instead of Onkelos' version (and omitted mention of the greatness of the angels) without being influenced at all by the Islamic understanding of the tree. Conversely, however, one cannot discount the possibility that PseudoJonathan himself was influenced by Islamic thought in his rendering of this verse. There are instances in Pseudo-Jonathan's translation in which such influence is indisputable, including his rendering of Gen $21: 21$, in which Ishmael's wives are listed as "Fatima" and either "Isha" or "Adisha," all relatives of Muhammad. ${ }^{64}$

The possibilities for the transmission to Saadiah of the tradition that elohim means angels in the context of Gen 3:5 are thus as follows: (1) Saadiah could have borrowed the translation from the Qur'an or another specifically Islamic source, with or without knowledge of Pseudo-Jonathan's translation; (2) Saadiah, without consideration of the Islamic tradition, could have borrowed from Pseudo-Jonathan, who himself borrowed from Islamic sources; (3) Saadiah, without consideration of the Islamic tradition, could have borrowed from Pseudo-Jonathan, who borrowed from the same pre-Islamic source that influenced the Qur'an; (4) Saadiah could have borrowed from the original pre-Islamic source without consideration of the Islamic tradition and without knowledge of Pseudo-Jonathan's Targum of Genesis; or (5) Saadiah could have been influenced by his Islamic cultural environment, in which the tradition that consuming the fruit would cause humans to become like angels was widely known.

The second and third options seem improbable. Given the extensive influence of Onkelos' translation on Saadiah's Tafsir, it seems unlikely that Saadiah would take from Pseudo-Jonathan only that element of the translation which is absent from Onkelos. The fourth option is possible, and indeed, one could argue that almost every

${ }^{64} \mathrm{Z}$. Gottlieb, "Targum Yonatan ben 'Uziel 'al ha-Torah," Melilah 1 (1944) 34 ' $\bar{A}$ 'isha and Khadija were wives of Muhammad, and Fātima was, the Prophet's daughter. According to Pseudo-Jonathan, ed. M. Ginsburger (Hildesheim, 1971), a critica edition of the text based on MS BM 27031, the names listed are 'Isha and Fatima: Ginsburger includes a note stating that some manuscripts read 'Adisha instead of 'Isha. Targum Yonatan ben 'Uziel 'al ha-Torah, ed. D. Rieder (Jerusalem, 1974), another critical edition based on the same manuscript, provides a different reading: Ishmael's wives are 'Adisha and Fatima, although some manuscripts read 'Isha instead of 'Adisha. parallel between the Tafsir and Islamic tradition is due to borrowing from a shared pre-lslamic source, but one would be hard pressed to prove that Saadiah had access to numerous 6th- and 7 th-century traditions that were preserved independently of Islamic sources into the 10th century but have subsequently disappeared. The last option is also possible, but relies on the presumption that this particular tradition had become part of the widespread cultural understanding of the Garden of Eden myth, much as contemporary westerners commonly consider the fruit of the tree to be an apple. This presumption is difficult if not impossible to prove, and it strikes me as improbable that the specific notion of Adam and Even becoming like angels would have gained universal cultural coinage to the extent that, for this reason alone, Saadiah considered it worthy of inclusion in his Tafsir. ${ }^{65}$ The possibility of cultural influence cannot be fully discounted as an explanation for Saadiah's translation, and it is in fact strengthened somewhat by the fact that the Karaite translations of Yefet and Yeshu'ah (which generally refrain from using Islamic terms and sources) also render Gen 3:5 using the word mala' $i k a$, yet it is also possible that these Karaite translators borrowed this translation directly from Saadiah and not from their cultural environment. ${ }^{66}$ The first option thus remains a distinct possibility: Saadiah, regardless of whether he knew Pseudo-Jonathan or whether this particular tradition had entered popular culture, decided to translate Gen 3:5 as referring to angels and not great men on the basis of his knowledge of the Qur'an or Islamic traditions based on it. This assertion of specifically qur'anic influence on the Tafsir , tentative on its own, is supported by Saadiah's unambiguous reliance on qur'anic material elsewhere, as detailed below.

${ }^{65}$ It should be noted that this explanation cannot account for Pseudo-Jonathan's translation, since Islam had not yet come to permeate the culture of Palestine in the 7th or 8 th centuries. The only options available to explain Pseudo-Jonathan on Gen 3:5 are to posit borrowing from Islam (as he clearly did in identifying the supposed wives of Ishmacl) or Pscudo-Jonathan"s usc of a pre-Islamic source that independently influenced the Qur'an.

${ }^{66}$ Blau, "Some Instances," pp. 21-28, attributes numerous similarities between the Tafsir and Karaite texts to borrowing from Saadiah's translation. Polliack notes the predilection of Yefet and Yeshu'ah toward de-anthropomorphizing God by means of reference to an angel, The Karaite Tradition, p. 89. Polliack bricfly discusses Gen 3:5 as an example of how translators replace the original meaning of a biblical word so as to avoid an anthropomorphic reference to God (p. 178); she does not address the question of why all three translators make the same replacement. 
Even if one is not willing to accept the attribution of Saadiah's translation of Gen 3:5 to the specific influence of the Qur'an, there is enough evidence to suggest the high likelihood of this translation being based on Islamic influence of some sort. The tradition that associates elohim with angels in this verse cannot be found before the rise of Islam, nor does it appear in a pre-Saadianic Arabic translation of the verse; Pseudo-Jonathan, Saadiah, and the Karaites, who all offer a translation of Gen 3:5 using the word for "angels," are all known to have been influenced in various ways by Islam. The implication of this attribution, however, is that Saadiah consciously chose to follow the Islamic interpretation of events in the Garden of Eden even though Onkelos offered a reasonable alternative. We are again faced with the question of why Saadiah does so, and again Saadiah's Commentary on this verse does not offer any guidance. ${ }^{67}$

\section{QUR'ANIC PARALLEL II: JOSEPH'S GARMENT}

We have now encountered the instances in which Saadiah elects to follow Islamic traditions over rabbinic interpretations (elohim, Gen 3:5) or over a straightforward reading of the biblical text (shur, Gen 16:7). Before addressing the crucial question of why Saadiah does this, one more instance of Islamic influence on the gaon's translation of the Book of Genesis is in order. This example was first noted at the beginning of the 20th century and debated in the pages of the Monatsschrift für Geschichte und Wissenschaft des Judentums. Adolf Schmiedl points out that, although in the rest of his Tafsir Saadiah translates the Hebrew word beged with the Arabic thawb (both of which mean "garment"), in the passage recounting Joseph's encounter with Potiphar's wife in Genesis 39 he repeatedly translates the word as qamīs, "shirt." ${ }^{68}$ Schmiedl explains the anomaly by

${ }^{67}$ Zucker, ed., Perushei Rav Seradiah, 3:5; see above, n. 60 .

${ }^{68}$ A. Schmied], "Randbemerkungen zu Saadja"s Pentateuchübersetzung," MGWJ 45 (1901) 127-129. This is the first of three related articles on the subject, published under the same title in different issues of the Monatsschrift from 1901-1902. Schmiedl is not quite accurate in his statement that, aside from Genesis 39 , Saadiah always translates beged as thawb. There is one other instance in which Saadiah does not translate beged as thawb; this exception, however, proves the rule. Saadiah translates the command to attach fringes "al kanfei bigdehem, "on the corners of their garments" (Num 15:38), to apply only to uzurhum, their shawls or outer garments. This translation, which Zucker does not discuss, is clearly intended to express Saadiah's understanding showing the parallel with Qur'an 12, the chapter about Joseph, in which the word qamis is used for the garment Joseph's brothers bring back to their father to prove his death (12:18), the garment which Joseph's would-be seducer ripped from behind (12:25-28), and the garment which Joseph sends back with his brothers to Jacob to prove that he is still alive $(12: 93) .{ }^{69} \mathrm{Schmiedl}$ concludes that the use of the word qamis in Genesis 39 is due to Islamic influence and that Saadiah could not possibly have inserted this word himself, both because Saadiah would not include references to the Qur'an in a translation of the Torah and because if he was indeed alluding to Sürat Yūsuf he would have availed himself of additional opportunities to include parallel language.

In a subsequent issue of the Monatsschrift, Wilhelm Bacher rejects Schmiedl's assertion that Saadiah would not have made references to the Qur'an in his Tafsir. Bacher cites as proof Saadiah's translation of the first phrase in Ps 18:32, rendered by JPS as "who is a god except the Lord," which Saadiah renders la iläh illa allāh, the traditional Islamic formula expressing God's unity. ${ }^{70}$ Bacher proceeds to explain the irregular use of the Arabic qamis for the Hebrew beged in the Joseph narrative by citing Ibn Ezra's commentary on Gen 2:11 (see above, p. 358) as proof that Saadiah was writing for an Islamic audience. As a result, Saadiah would naturally wish to include references to the Qur'an in his translation, particularly in his rendition of the Joseph narrative which, according to the Qur'an, is ahsān al-qasas, "the fairest of stories."71 Bacher's argument,

of the commandment regarding șisit, and for this reason Saadiah strays from a litera translation of thawb. Without good rcason to do so, however, Saadiah remains consistent in his translation

${ }^{69}$ It should be noted that Saadiah only uses the word qamis in conjunction with the second of these passages. For the special tunic Jacob gives Joscph in Gen 37:3 (Hebrew: ketonet passim), Saadiah translates tünia dibäj, or, in the London Polyglot, jabba dibāj; the latter version means "adorncd coat." (For the meaning of tünia dibäj, see below, n. 73.) In the biblical account of the Joseph narrative, Joseph docs not send a garment back to his father to prove that he is still alive.

${ }^{70}$ Bacher here cites his own earlier work, Abraham Ibn Esra's Einleitung zu seinem Pentateuch-Commentar (Vienna, 1876), p. 34, which contains additional references to Islamic terms used in Saadiah's translation of Psalms and other works, including the terms imām and rasūl discussed above, pp. 361-365.

${ }^{71}$ W. Bacher, "Notizen," pp. 565-566. The phrase ahsän al-qașas comes from Qur'an 12:3 
however, is untenable in light of the recent scholarly arguments, mentioned above, that Saadiah did in fact write his Tafsir in JudeoArabic for a Jewish audience and not an Islamic one.

Another difficulty with Bacher's explanation is that it fails to address Schmiedl's second argument: if indeed Saadiah consciously includes qur'anic references for the benefit of Islamic readers, why does he fail to include even more references to the sūra about Joseph? As Schmiedl notes, Saadiah could have rendered the phrase in Gen 37:25, orhat yishma'elim, "a caravan of Ishmaelites," using the word sayyāra, following Qur'an 12:19 and in consonance with Onkelos' Aramaic translation (sheyarat 'arba'ei). Instead, Saadiah translates the word for caravan as qafila (the two Arabic words are synonyms), and misses an easy opportunity to allude to the qur'anic version of the story. ${ }^{72}$ Similarly, Saadiah could have referred to the tunic Jacob gave Joseph in Genesis 37 as a qamis to strengthen his qur'anic allusion, but instead calls it a tūnia. ${ }^{73}$ Such "missed oppor-

\footnotetext{
${ }^{72}$ Schmiedl, "Randbemcrkungen" (1901), p. 128.

${ }^{73}$ The word tünia, which Saadiah consistently employs as a translation of the Hebrew ketonet, does not exist in classical Arabic dictionaries, according to Y. Avishur, "'Millim Qashot' be-Targum Rasag la-Torah ve-Gilguleihen be-Nusha'ot ha-Targumim ba-Mizrah," Mesorot 3-4 (1989) 140-142. This word is indeed missing from Lane's Arabic-English Lexicon and other dictionaries of classical Arahic, as well as from $\mathrm{R}$. Dozy, Dictionnaire détaillé des noms des vêtements chez les arabes (1845; repr., Beirut, n.d.), where a reference might have been expected. It does, however, appear in R. Dozy, Supplément aux Dictionnaires Arabes (1881; repr., Beirut, 1968), a work based primarily on modern and early modern Moroccan sources, and in H. Wehr, $A$ Dictionary of Modern Written Arabic, ed. J. M. Cowan (1974; repr., Beirut, 1980), a work heavily reliant on Egyptian sources. Both dictionaries offer the same definition for the word tünia, which Wchr renders as "alb of priests and deacons." An alb is a special white linen robe worn hy priests in the celebration of the Mass.

Saadiah's use of the term tünia dihāj may be an example of Christian influence on Saadiah's thought in general and on the Tafsir in particular, although I make no claims to have examined this subject in any depth. Another possible Christian influence on the Tafsir is the term Saadiah uses to express God's physical presence without resorting to anthropomorphism; Saadiah's phrase of choice, nür alläh (see above, n. 9), may be related to the Christian practice of referring to Christ as al-nür (see Wehr, A Dictionary, s.y. nür). Further examination of these and other potential parallels may prove instructive. It would not, however, affect the strength of the present thesis that Saadiah utilized Islamic sources in his translational work, as the possibility of one type of influence does not exclude the possibility of another also existing. If anything evidence that Saadiah relied on Christian as well as Islamic sources would strengthen the possibility, insufficiently supported by this study, that Saadiah was open to incorporating into his work information he considered to be valuable regardless of his opinion of
}

tunities" abound in Saadiah's translation. To cite only a few examples, Saadiah uses a different word than the Qur'an for Noah's ark $(t \bar{a} b \bar{u} t \text { instead of } f u l k)^{74}$ and fails to use any parallel language in his version of the Abraham and Sarah narrative or in the story of Moses' birth. Although Saadiah could easily have used the same word as the Qur'an (al-hajr) to identify the two rocks which Moses strikes in the desert (Exod 17:6, Num 20:7, cf. Qur'an 2:60, 7:160), he chooses instead to use more specific Arabic words (al-sawān, alșakhr) to better reflect the biblical Hebrew. ${ }^{75}$ Nor does Saadiah adopt the Islamic interpretations of verses said to foretell the coming of Muhammad. Camilla Adang lists eight passages from the Torah considered by Islamic polemicists to foretell the coming of Muhammad; with the exception of Saadiah's translation of the placename shur, there is nothing in Saadiah's translations of these passages that would provide any support for these claims. ${ }^{76}$ For each example of Islamic borrowing in the Tafsìr, there are countless potential borrowings that do not occur. It is therefore impossible to

the religion from which it originated; whatever Saadiah's attitude toward Islam, his perception of Christianity was ccrtainly a negative one. On the suhject of Saadiah's attitude toward these religions, see the articles cited above, n. 21, as well as D. J. Lasker, "Saadya Gaon on Christianity and Islam," The Jews of Medieval Islam: Community, Society, and Identity, ed. D. Frank (Leiden, 1995), pp. 165-177; E. Schlossberg, "Neged Mi Mitpalınes Rav Secadiyah Gaon be-Diyyuno be-Bițul ha-Torah? Teshuvah le-Ma'amaro shel Prof. Lasker," Da'at 32-33 (1994) 13-17.

${ }^{74}$ The Arahic word $t a b \bar{u} t$ is related to the Hehrew word tevah used in Genesis to refer to Noah's ark; hoth literally mean "chest" or "box." The proper Arabic word for a ship or ark is fulk and appears in Quran 7:64; an alternative is safina, used by such figures as Ibn Qutayba (d. 889) and al-Ya'aqūbī (d. 897), both of whom make extensive use of biblical materials. (I am grateful to Camilla Adang for bringing these references to my attention.) Saadiah, using a cognate word, conforms to the literal meaning of the biblical Hcbrew rather than offering a more interpretive translation that would have matched Islamic tradition; on Saadiah's use of cognate words in his translation, see above, n. 22

${ }^{75}$ The Hebrew word for "rock" in Exod 17:6 is sur (boulder), while in Num 20:7 the word is sela' (cliff). Saadiah is consistent throughout his Tafsir in translating the Hebrew even (rock) with the Arabic al-hajr and the word sur with al-sawwän; in one poetic reference (Deut 32:13), he translates sela ${ }^{\star}$ as al-hajr, but otherwise that word is translated consistently as al-sakhr. Lane's Arabic-English Lexicon, relying on the $1 \mathrm{lth}$-century Iraqi lexicographer al-Jawharī, translates sawwän as flintstone or hard stone and sakhr as "great masses of hard stone."

${ }^{76} \mathrm{C}$. Adang, Muslim Writers on Judaism and the Hebrew Bible: From Ibn Rabban to Ibn Hazm (Leiden, 1996), p. 264. 
conclude that, on the occasions when Saadiah does rely on Islamic sources, he does so for the express purpose of creating parallels between his work and Islamic texts and traditions. Why, then, does Saadiah insert Islamic references into his Tafsir at all?

Polliack's hypothesis regarding the influence of Saadiah's Islamic cultural environment on his translation is unable to account for instances in which the Tafsìr adopts specific and selected elements from Islamic texts or traditions. According to popular Islamic belief, Hagar was not only on the road to Mecca, she actually went there along with Abraham and Ishmael. The fact that Saadiah lived in an Islamic society, and was therefore presumably aware of this version of the story, does not account for why he incorporates it in any form into the Tafsir or why he does so only to the limited extent of saying that Hagar was traveling toward Mecca. A similar point can be made regarding his rendering of the Garden of Eden myth: the gaon does not incorporate the most important aspect of the qur'anic version-that the tempter was Iblis, a fallen angel traditionally associated with the devil-but he does incorporate the apparently minor detail that the fruit of the tree causes one to become like the angels. One can also question whether the Islamic details which the gaon incorporates into his translation were in fact widely known in Arabic culture. Could Saadiah have expected his readers to know that the fruit of the tree causes one to become like the angels? It is quite possible that the story of Joseph's seducer ripping his garment from behind was well known, but was the fact that this garment was a shirt so commonly accepted that Saadiah felt compelled to offer a non-literal translation to conform to cultural expectations? Polliack's hypothesis is valuable, but insufficient; a supplementary hypothesis is needed.

I would suggest that Saadiah considers Islamic sources to contain accurate information and insights regarding biblical history. The Bible merely refers to Joseph's clothing in Genesis 39 as a "garment," but the Qur'an specifies that the garment is in fact a shirt. Saadiah, accepting the veracity of the qur'anic account, therefore translates the general Hebrew word beged with the specific Arabic word qamis. Similarly, the biblical account of Hagar's flight from Sarah states that the angel found her on the road to Shur, but does not mention her intended destination. Relying on the Islamic tradition that Hagar went to Mecca, Saadiah inserts hajr al-hijāz as the intended final destination of her journey instead of Shur, which would merely be a landmark along the way. The Torah merely states that Moses is a nabi, a prophet; the gaon, where appropriate, sharpens this description by using the more specific word for an elite, Scripture-bearing messenger, rasiul. In the passage about the fruit of the tree, Saadiah uses the Qur'an not to provide a more specific description of a biblical event but rather to clarify an ambiguous biblical passage which could not be interpreted literally; evidently, Saadiah considers the Qur'an's clarification to be preferable for whatever reason to that of Onkelos in this case. Saadiah does not, however, use qur'anic language when the Bible is clear and specific. For this reason, Joseph's tunic in Genesis 37 remains a tünia even though Qur'an 12:18 states that it is a qamis, and the rocks which Moses strikes are called by their specific names and not the generic, qur'anic hajr.

In certain cases Saadiah is clearly willing to adopt Islamic understandings of the biblical text over those of respected rabbinic interpreters, and indeed over the evident meaning of the text itself; otherwise, there would be no reference to angels in Saadiah's version of Gen 3:5 and no reference to the Hijaz in Gen 16:7. Saadiah trusted and relied directly upon Islamic texts and traditions in order to interpret certain imprecise or problematic biblical passages, interpretations which cannot be explained simply by reference to Saadiah's sensitivity to his cultural environment. This is the most plausible way to understand the qur'anic and traditional parallels which we have examined so far, and also helps to explain Saadiah's use of certain Islamic terms and concepts. It is also the only way, in my opinion, to account for the next and final example of Islamic influence on Saadiah's Tafsìr.

\section{QUR'ANIC PARALLEL III: THE COLOR OF THE COW}

The Book of Numbers contains another instance in which the gaon appears to rely on the Qur'an for authentic information about a biblical narrative. This case, however, is more complicated than those from Genesis which we have already encountered because of the nature of the language that Saadiah borrows. The relevant passage is Qur'an 2:64-71, which describes what happened when God, through Moses, commands the Children of Israel to sacrifice a cow. The people, doubting Moses' message, repeatedly demand that the prophet ask God to clarify what sort of cow should be sacrificed. 
Moses reports that the cow should be middle-aged, a pleasing color of yellow, and be both unblemished and never used for labor. Of most interest in the present context is the second of Moses' three answers, contained in the latter portion of 2:69: qāla innahu yaqūlu innahä baqara safrā' fãqi lawnuhà tasurru al-nāzirin, "He [Moses] said, 'He [God] says that she is a yellow cow, her color is free from admixture, those who see her are gladdened." Satisfied by Moses' answers, the people sacrifice the appropriate cow. This narrative is immediately followed by two enigmatic verses relating to the murder of an Israelite in which the sacrificed cow appears to play some role in either resurrecting the deceased or identifying his murderer.

Although there are substantial differences, this qur'anic story seems to be related to the biblical command to sacrifice an unblemished and unworked red heifer whose ashes are used to purify those who have become ritually impure through contact with corpses (Numbers 19). The key verse of interest here is Num 19:2, the second portion of which is translated by JPS as "Instruct the Israelite people to bring you a red cow (parah adumah) without blemish, in which there is no defect and on which no yoke has been laid." Saadiah translates this verse almost the same way, and most modern scholars have failed to note anything unusual about the Tafsir's interpretation of the verse. There is, however, one significant departure from the biblical text: according to every manuscript and edition of the Tafsir which 1 have been able to examine, the color of the cow is safra $\bar{a}^{\prime}$, the qur'anic word describing the cow's color. ${ }^{77}$ It appears that Saadiah considers the red heifer to be yellow.

There can be no explanation for Saadiah's use of the word safra' in this particular context other than that he is reliant on Qur'an 2:69, as there are no rabbinic sources which suggest that the cow was anything but red. But why would Saadiah contradict the unambiguous meaning of the biblical text, not to mention the entire rabbinic tradition of interpreting this verse, in favor of the Qur'an's understanding of the cow's color? Saadiah borrows no other elements of this quranic narrative, and even uses different vocabulary to translate the command that the cow be unblemished and not have been forced to work; as we have seen elsewhere, Saadiah is not merely incorporat-

${ }^{7}$ I exaggerate here slightly: Derenbourg's edition misprints the word safra $\bar{a}^{\prime}$ by placing an extraneous diacritical dot above the first letter, resulting in the nonsensical word qufră'. ing qur'anic language into his Tafsir for its own sake. Surely, Saadiah feels under no cultural pressure to conform to a particular Islamic color scheme. And there is no doubt that the standard meaning for the word safrä' in classical (as well as modern) Arabic is indeed "yellow" and not "red." Although terms for different colors develop and change over time, the distinction between "red" and "yellow" is considered to occur relatively early in a language's development, and is already clearly apparent in pre-Islamic poetry. ${ }^{78}$ One cannot, therefore, assert that Saadiah understood the qur'anic term safra $\bar{a}^{\prime}$ to mean the same thing as the biblical word adumah.

Joseph Qafih, however, attempts to do so. In his translation of deviations from the literal meaning of the biblical text found in Saadiah's Tafsir, which appears as one of the numerous biblical commentaries in the Torat Hayyim series, Qafih notes that Saadiah also uses the root s.f.r. in his translation of Job 16:16. That verse begins panai homarmeru mini bekhi, "My face is red with weeping"; Saadiah's translation reads wa-'sfarra wajhi min al-buka' ${ }^{79}$ Qafị argues that since the root s.f.r. in Saadiah's Tafsir of Job appears to signify "redden," by implication the adjective safra $\vec{a}$ ' in Num 19:2 should mean "red." 80 This logic is flawed, however, since Saadiah may not have provided a literal translation of Job 16:16 either. According to the dictionaries of both Dozy and Wehr (based on modern sources), the expression asfarra wajh means to turn pale, which one can reasonably understand as a result of crying. Although I have not found a classical Arabic dictionary that defines this expression

${ }^{78}$ D. J. Stewart, "Color Terms in Egyptian Arabic," The Language of Color in the Mediterranean ed A Borg (Stockholm, 1999), pp. 105-106. For a detailed study of color in pre-Islamic Arabic litcrature, see W. Fischer, Farb-und Formbezeichnungen in der Sprache der Altarabischen Dichtung (Wiesbaden, 1965), pp. 233-382.

The vast majority of entries in Lane, Arabic-English Lexicon, s.v. s.f.r., are related to the color yellow or to something that is yellow, including gold and brass, the color of wheat just before it is fully ripe, dry herbage, barley, dates, and a certain stomach ailnent which produces yellow water in the stomach or causes the victim's face to turn yellow. Lanc does report that the Misha of al-Fayyūni translates the word sufra as "a ccrtain colour, well known, less intense than red, found in animals and in some other things, and . . . in water." By "less intense than red," al-Fayyūmì does not mean light red but rather what we call "yellow" which, according to Fischer, fits that description in early forms of Arabic; sec Farb-und Formbezeichnungen, p. 237.

${ }^{79}$ See Bacher, ed., Sefer lyyov u-Seraho, ad loc.

${ }^{80} \mathrm{~J}$. Qafih, Tirgum ha-Tafsir shel Rav Se'adiah Ga'on (Jerusalem, 1984), reprinted in Torat Hayyim (Jerusalem, 1986), Num 19:2. 
explicitly, several do report that the word safar means "a certain disease in the belly, which renders the face yellow [yasfarra minhi alwajh]." ${ }^{81}$ It appears that Saadiah uses a colloquial expression in his translation of Job 16:16, which therefore cannot be used to show how he defines the word safra ${ }^{\prime}$.

One should also note that the Hebrew adom, "red," is the only color in the Torah which Saadiah translates using more than one Arabic root. While the Hebrew words for white, black, green, and yellow are all paired with one Arabic root ${ }^{82}$ words related to the color red are translated using three different roots. The Hebrew word me'addamim, which refers to tanned or reddened animal skins (Exod 25:5, 26:14, 35:7, 35:23, 36:19), is translated with the cognate Arabic word adim. All other forms of the color adom are translated with the Arabic root h.m.r., with the glaring exception of Num 19:2, which is rendered safra $\bar{a}^{3} .{ }^{83}$ Since Saadiah is generally consistent in his translations and since there is no strong evidence to the contrary, it is rather far-fetched to assert that Saadiah deviated from his standard Arabic equivalent for the word "red" in favor of another word which, although it is generally defined as "yellow," Saadiah himself defines as "red." Rather, it appears that Saadiah consciously chooses to forego a literal translation of the cow's color in favor of the qur'anic parallel. Why?

${ }^{81}$ Dozy, Supplément, s.v. s.f.r.; Wehr, A Dictionary, s.v. s.f.r. The translation of safar is taken from Lane, Arabic-English Lexicon, s.v. s.f.r., who credits this definition to the Muhkam of Ibn Sida (d. 1066) and the Qamüs of Firuzabadi (1329-1414); this definition also appcars in the Lisān al-'Arab of Ibn Mukarram (1233-13J1), which I consulted in reproducing the Arabic in this definition.

${ }^{82}$ Saadiah translates the Hebrew șahov with its Arabic cognate, așhab. (On the subject of cognates in Saadiah's translation, see above, n. 22.) Fischer, Farb- und Formbezeichnungen, pp. 369-373, explains that ashab is a subset of the broader color catcgory asfar and connotes "blond" or "light yellow."

${ }^{83}$ The only other occasions of which I am aware in which Saadiah uses the root $s, r$ in his translations are his rendering of Job 16:16, discussed above, and his translation of the precious stone bareqet in Exod 28:17,39:10. JPS.translates this stone as "emerald," and it seems that Onkelos also considers the stone to be green in hue. As noted above, Ibn Ezra disapproved of Saadiah's translations of "families, cities, animals, birds, and rocks" (Ibn Ezra on Gen 2:10, cited above, n. 16); he ridicules Saadiah for understanding the word bareqet as deriving from the word baraq, lightning, in his Shorter Commentary on Exod 28:30. Qafih, Tirgum ha-Tafsir, Exod 28:17, offers the gloss "green like gold" to explain why Saadiah uses a word related to gold to describe a roek generally considered to be green.
Qafin, in his first collection and translation of excerpts from Saadiah's Tafsir (published over twenty years before the collection that appears in the Torat Hayyim series), offers the following answer.

[The word safrä' means] yellowish-brown, like the color of a dark egg yolk, which is the natural color and shade of most cows. And the command is that [the cow being sacrificed] should be entirely of one shade and not of a mixture. But actual red like blood is something that does not exist in reality and, if it could be found, would be nothing less than a great wonder. And it is not possible that [the Children of Israel] would be commanded regarding something that is not natural. ${ }^{84}$

Qafin makes the argument that Saadiah was unwilling to accept the literal meaning of the biblical verse for reasons associated with his belief that all divine commandments can be accomplished in this world. The rabbinic tradition acknowledges the extreme rarity and consequent value of red heifers (e.g., bQid 31a), but never questions the notion that cows can indeed be red; Saadiah, according to Qafih, disagrees. Since Saadiah does not believe that red cows exist naturally, he cannot accept the notion that God commanded the Children of Israel to sacrifice one and therefore picked a more natural color (Qafih does not notice the qur'anic influence here). ${ }^{85}$ But is yellow (even dark-yolk yellow) a natural color for cows? Classical Islamic commentators on Qur'an 2:69 maintain that it is not. The preeminent Sunni commentator Abū Ja'far Muhammad Ibn Jarīr al-Tabarī (Baghdad, 839-910 CE), a near contemporary of Saadiah, reports that because the Children of Israel asked for details about what kind of cow to sacrifice in order to cause trouble, God made it harder for them to find the proper cow, which could only be obtained at great cost. ${ }^{86}$ Qafin himself seems to have had second thoughts about this

${ }^{84}$ J. Qafih, Perushei Rabbenu Se adiah Ga'on la-Torah (Jerusalem, 1963), Num 19:2. The translation is mine.

${ }^{85} \mathrm{Had}$ Saadiah in fact wanted to use a word connoting a morc realistic shade of red for cows, he could have used the term ashqar, which connotes deep red or reddish brown and is used to refer to sorrel horscs; see Fischer, Farb- und Formbezeichnungen, pp. 343-346.

${ }^{85}$ Al-Tabarī, Tafsìr al-Tabari: Jāmí al-Bayān fĩ Ta'wìl Ayy al-Qur'ānn, eds. M. M. and A. M. Shakir (Cairo, 1954), 2:185-187. See also M. Ayoub, The Qur'an and Its Interpreters (Albany, 1984), 1:116-119. Many of the lslamic traditions rcgarding the ycllow cow contained in the collections of both al-Tabari and Ayoub are strikingly similar to the talmudic account of how the red heifer was procured (bQid 31a). 
interpretation, since he replaced it with the Job argument in his more recent collection of Saadiah's interpretive translations.

The key to understanding Saadiah's use of the word safra ' ' in this context, a term clearly derived from the Qur'an, is to examine how Saadiah's Muslim contemporaries interpreted the quranic passage. Al-Tabarī's commentary contains several different understandings of the phrase from Qur'an 2:69, but the one apparently accepted by alTabari himself is that safrā' fāqi' lawnuhā means "black (aswad), intense in its blackness." He states that a black camel is typically described as being safr, "and this is said regarding camels because their blackness inclines toward yellowness." 87 This understanding of the root s.f.r. when applied to animals as connoting blackness is also mentioned in the dictionary al-Sihäh by al-Jawharī, who studied in Baghdad and died in the early 11 th century. ${ }^{88}$ It appears that medieval Iraqis understood the word $s a f r a{ }^{\prime}$ to mean black in certain contexts as well as yellow, and al-Tabarī applied this understanding of the word to the qur'anic reference to the cow. It is not unreasonable to argue that Saadiah understood the qur'anic reference to $b a$ qara safrä' in the same manner as his nearly contemporaneous and geographically proximate Islamic counterpart, and that Saadiah used the qur'anic word $s a f r a{ }^{\prime}$ in his translation of Num 19:2 to mean black, not yellow and not red. Given the fact that Saadiah is known to have shared al-Tabarī's style of exegesis, ${ }^{89}$ it is also quite possible that Saadiah learned this interpretation directly from the work of al-Tabarì

Saadiah's use of the word safra $\bar{a}^{\prime}$ to refer to the biblical heifer, if understood in light of al-Tabari's interpretation of that word in the context of Qur'an 2:69, corresponds perfectly with what we have already seen about the gaon's interpretive method. As Qafih correctly notes in his earlier collection, Saadiah was troubled by what he perceived to be the scientific impossibility of cows being a natural shade of red. He wished to eliminate the logical as well as theologi-

${ }^{87}$ Shakir and Shakir, eds., Tafsir al-Tabari, 2:199-200. The other alternatives alTabari cites in his Tafsir are: the horns and hooves were yellow, the cow was untamed, and the cow really was yellow. On the word asfar in connection with the color of animals in general and blackish animals in particular, see Fischer, Farb- und Formbezeichnungen, pp. 363-365.

${ }^{88}$ Al-Jawharī, Tāj al-Lugha wa-Sihāh al-'Arabiyya (Beirut, 1979), s.v. s.f.r. This definition also appears in the earlier dictionary of al-Azhari (895-981).

${ }^{89}$ See above, n. 21. cal difficulty associated with a divine commandment reliant upon the occurrence of the miraculous. Consequently, Saadiah chose to "mistranslate" the word adumah as safra qur'anic parallel in 2:69 which — as he and some Islamic interpreters understood it-offers a more realistic and less theologically problematic description of the cow. Although Saadiah's use of this particular qur'anic term cannot be ascribed to general cultural influence, his interpretation of that term must be understood in light of his cultural context. The translation of Num 19:2 indicates that the gaon knew and relied on the Qur'an in a manner parallel to, if not derived from, the way in which it was interpreted by his contemporaries. This example again shows Saadiah's use of Islamic sources (cf. qamis in Genesis 39) to resolve difficulties in the Bible (cf. elohim in Gen $3: 5$ ), even when these sources directly contradict the evident meaning of the biblical text (cf. shur in Gen 16:7). Our discussion of this particular passage also demonstrates that Saadiah did not learn the Qur'an in a vacuum; his understanding of that text must be understood in light of contemporary Sunni Islamic interpretations (cf $m^{\prime} t^{\prime} a$ in Deut 23:18), with which he may well have been familiar.

\section{CONCLUSION}

It was stated at the outset of this article that Saadiah had at least five distinct objectives in mind in writing his Tafsir: to provide an Arabic rendering of the "plain text of the Torah," to educate and guide the assimilated Jewish masses of his day, to provide a translation of the Torah in accord with reason, to provide a translation of the Torah in accord with rabbinic tradition, and to refute heretical and Karaite beliefs. Because Saadiah consciously limits his Tafsir to the format of a translation and not a commentary, he addresses many of these objectives only indirectly by offering, for example, a rabbinic translation of the verses about boiling a kid in its mother's milk. Such a translation both brings the Written Law into conformity with the Oral Law and refutes heretical assertions that rabbinic law has no biblical basis. Saadiah's use of Islamic sources obviously cannot serve to advance either of these two objectives, but the specific Islamic terms and traditions he employs in the Tafsir do appear intended to advance the gaon's other goals.

Saadiah was interested in providing a complete and accurate account of the biblical text to an Arabic-speaking audience. He therefore uses precise Arabic terms, such as $i m \bar{a} m$ and $r a s \bar{u} l$, even though 
these terms have Islamic connotations which the more generic cognates kāhin and nabi do not have. He also replaces imprecise biblical language about particular myths with more specific information drawn from the Qur'an and Islamic tradition. As a result of this borrowing, the gaon is able to inform his audience that Hagar was not merely on the road to Shur but was in fact headed for Mecca, and that the article of clothing torn off of Joseph by his seducer is specifically a qamis. From Saadiah's perspective, the only accurate interpretation of the Bible is one that conforms to reason, and the gaon makes use of Islamic sources to interpret passages that might appear to be irrational. Saadiah turns to the qur'anic version of the myth about the fruit of the tree in order to translate the problematic biblical word elohim, and considers the qur'anic color of the special cow to be more reasonable and therefore more accurate than the color stipulated in the Torah and unhesitatingly accepted in talmudic sources. Saadiah's use of well-known Islamic terms and traditions in order to produce a more complete, accurate, and rational rendition of the Torah also serves to advance his goal of reaching an assimilated Jewish audience. The gaon's attention to proper Arabic literary style and his use of a phraseology derived from Islamic sources similarly further this goal. Saadiah's insertion into the Torah of a prohibition against mut' $a$ can also be understood in light of his interest in educating the Jewish masses.

A close reading of Saadiah's Tafsir in light of its Islamic parallels indicates that the gaon was quite knowledgeable about the dominant religion of his time, and in certain respects quite accepting of its traditions. Islam's influence on Saadiah accounts not only for his rationalist philosophy but also for some of the specific ways in which he reconciled that rationalism with the biblical text and in which he presented that text to his assimilated Jewish audience. Saadiah certainly was not trying to syncretize Judaism with Islam or write an Islamicized translation of the Torah for the benefit of Muslims; had he so desired, he could easily have incorporated many more references to the Qur'an into his Tafsir. The gaon was, however, willing to take from Islam those terms, traditions, and insights which he found to be valuable for his own purposes, and he was able to integrate them successfully into a work that remains quintessentially Jewish, so much so that his Tafsir came to be accepted as the authoritative rabbinic translation of the Torah into Arabic.

It may prove worthwhile to examine the way in which Islamic elements incorporated into Saadiah's Tafsir affected subsequent bib- lical interpretation. On the one hand, many subsequent interpreters adopted certain translations that show evidence of Islamic influence, including the gaon's understanding of Gen. $3: 5 .{ }^{90}$ On the other hand, we have seen that many copyists were unwilling to accept the Tafsir's one obvious and affirmative reference to Islamic tradition, the statement that Hagar was on the road to Mecca when she met the angel of God. Did subsequent rabbinic commentators generally adopt other interpretations in the Tafsir based on Islamic sources, such as the color of the purificatory heifer or the meaning of the word qedeshah? Did subsequent Jewish writers follow Saadiah's practice of using Islamic terminology or adding descriptions to the name of God? Who noticed the gaon's use of Islamic material, and how was that use regarded? Did Islam's influence on Saadiah and on his Tafsir have any lasting impact within Judaism? However these questions may ultimately be answered, this study serves to reinforce the importance of considering the role of Islam seriously when examining Judaism in the medieval Arabic-speaking world in general and the works of Saadiah Gaon in particular, not only as an external force in conflict with Judaism but also as a resource available to be tapped and selectively incorporated into normative Jewish thought. ${ }^{91}$

\footnotetext{
${ }^{90}$ See, for example, the comments of Ibn Ezra, David Qimhi (Radak), and Hizqiya b. Manoah (Hizkuni) on Gen 3:5, all of whom accept the translation of ke-clohim as ke-malakhim without hesitation. Not all of Saadiah's changes, however, met with universal acceptance among the European interpreters of the Torah even when Saadiah's interpretation was uscd by one or another Arabic-speaking commentator. As noted above (see n. 56), Ibn Ezra builds on Saadiah's translation of shur as Mecca in his comment that the spring at which the angel appeared to Hagar is the spring of Zamzan associated with the haji pilgrimage. Radak, in contrast, specifically notes in his commentary on Gen 16:8 that the well is on the road to Shur, located at the border with Egypt; see David Qimhi, [Commentary] on the Book of Genesis, ed. M. Katzenelbogen (Jerusalem, 1980), reprinted in Torat Hayyim, vols. 1--2 (Jerusalem, 1986), Gen 16:8. In another instance of Satadiah's translation entering into medieval European commentary literature, Radak notes Saadiah's translation of mesha as Mecca in his comment on Gen 10:30; Ibn Ezra does not comment on this verse. Blan, "Some Instances," attributes the use by Karaite translators of ima $m$ as a translation of kohe' to the intluence of Saadiah's Tafsir; sce above, n. 24.

${ }^{91}$ [ wouId like to express my appreciation for the detailed comments and constructive criticism provided on earlicr drafts of this work by Raymond Scheindlin of the Jewish Theological Seminary and by Camilla Adang of Tel Aviv University, one of the readers for $J Q R$.
} 